Article

\title{
The Uncharacteristic Occurrence of the June 2013 Biomass-Burning Haze Event in Southeast Asia: Effects of the Madden-Julian Oscillation and Tropical Cyclone Activity
}

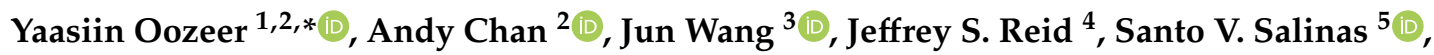 \\ Maggie C. G. Ooi ${ }^{6,7}$ and Kenobi I. Morris ${ }^{8,9}$ (i) \\ 1 Department of Geography and Environmental Management, University of Waterloo, \\ Waterloo, ON N2L 3G1, Canada \\ 2 Faculty of Science and Engineering, University of Nottingham Malaysia Campus, Semenyih, Selangor 43500, \\ Malaysia; andy.chan@nottingham.edu.my \\ 3 Department of Chemical and Biochemical Engineering, College of Engineering, University of Iowa, Iowa \\ City, IA 52242, USA; jun-wang-1@uiowa.edu \\ 4 Marine Meteorology Division, U.S. Naval Research Laboratory, Monterey, CA 93943, USA; \\ jeffrey.reid@nrlmry.navy.mil \\ 5 Centre for Remote Imaging, Sensing and Processing, National University of Singapore, Singapore 119076, \\ Singapore; crsscsv@nus.edu.sg \\ 6 Cloud and Aerosol Lab, Department of Atmospheric Sciences, National Central University, Chung-Li 32001, \\ Taiwan; chelgee.ooi@gmail.com \\ 7 School of Mathematical Sciences, University of Nottingham Malaysia Campus, Semenyih, \\ Selangor 43500, Malaysia \\ 8 Department of Mechanical Engineering, Ashesi University, Cantonments, Accra PMB CT3, Ghana; \\ kenobimorris@yahoo.com \\ 9 Center of Excellence for Sustainable Innovation and Research Initiative (CESIRI), \\ Port Harcourt 511101, Nigeria \\ * Correspondence: yaasiinoozeer@gmail.com; Tel.: +1-438-887-8774
}

Received: 15 November 2019; Accepted: 13 December 2019; Published: 1 January 2020

check for updates

\begin{abstract}
One of the worst haze events to ever hit Peninsular Malaysia occurred in June 2013 due to smoke from Riau, Central Sumatra. While biomass-burning in the region is common, the early occurrence of a haze episode of this magnitude was uncharacteristic of the seasonality of extreme fire events, which usually occur between August and October in the Maritime Continent (MC). This study aims to investigate the phenomenology of the June 2013 haze event and its underlying meteorological forcing agents. The aerosol and meteorological environment during the event is examined using the Moderate Resolution Imaging Spectroradiometer (MODIS) active fire hotspot detections and aerosol optical thickness retrievals, satellite-based precipitation retrievals, and meteorological indices. These datasets are then supported by a WRF-Chem simulation to provide a comprehensive picture of the event's meteorology and aerosol transport phenomenology. While extreme fire events are more characteristic of El Nino years, the MODIS fire count over the MC in June for the years 2001-2015 was highest in 2013 when neutral El Nino/Southern Oscillation (ENSO) conditions prevailed. Although, the mean daily precipitation for June 2013 was below average for June 2003-2015. An early active tropical cyclone (TC) season occurred in 2013, and results show that the combined induced subsidence and flow enhancement due to TC Bebinca and the dry phases of a strong Madden-Julian Oscillation (MJO) event contributed to the event intensification. Results also show that Bebinca induced a decrease in surface relative humidity of at least $10 \%$ over Riau, where fire hotspots were concentrated.
\end{abstract}


Keywords: WRF-Chem; biomass burning haze; Maritime Continent; tropical cyclone; MJO; ENSO

\section{Introduction}

Biomass-burning haze (BBH) in Southeast Asia (SEA) is an environmental concern that has attracted much attention during the past decade. Consequently, numerous studies have been performed to understand and characterize the occurrence of regularly occurring haze episodes [1-4]. Throughout the Maritime Continent (MC), agricultural waste burning, intentional forest fires to convert forests to agricultural land, and related peat burning have been the major causes of extreme haze episodes $[1,2,5,6]$. Such events are reported to have had alarming detrimental health effects on the populations affected most by the respective episodes [7-10]. Fire in the MC is most widespread during the drier boreal summer southwest monsoon season with a fire season that usually runs from June to October with the bulk of the fire occurring between August and early October [4]. In contrast, agricultural and forest fire activity peaks in boreal spring from late February to early May in northern SEA, when dry monsoonal conditions prevail over that region [2,6,11-13]. Fire activity generally starts earlier in the west of the MC with the start date propagating eastward. In fact, fire activity is a combination of economic factors and environmental opportunity. The economic factors of land clearing and agricultural maintenance are well entrenched in SEA. The meteorology of dry spells provides an opportunity to burn. Therefore, if we understand the meteorological phenomenology that leads to favourable fire weather, we can then start to understand and predict burning and its consequences.

There are several meteorological factors that influence observed burning activity at different temporal scales in the MC [4]. El Nino/Southern Oscillation (ENSO) [14,15] is the strongest indicator of total burning in the $\mathrm{MC}$, and during El Nino years, the already prevailing drier conditions are generally intensified, which results in more intense haze events [4,16-19]. While ENSO influences inter-annual fire activity, the wet and dry phases of the Madden-Julian Oscillation (MJO) [20-23] over the MC largely modulate intra-seasonal fire activity in the region [4,24]. The MJO is a 30-90 day large-scale coupled pattern of meso-synoptic scale circulation and deep convection that propagates eastward at a speed of $\sim 5 \mathrm{~m} \mathrm{~s}^{-1}$ through regions of the Indian Ocean and the Pacific Ocean where the sea surface is warm $[20,21,23]$. MJO activity can be classified into eight phases. In phase 1 , enhanced convection associated with MJO genesis occurs over Africa and the western Indian Ocean. By phases 2 and 3, convection is present over the Indian Ocean and approaches the MC by phase 4 . Convection enters the Pacific Ocean during phase 5, which induces significant drying over the MC. Maximum drying occurs over the MC during phases 6 and 7 as convection propagates further over the Pacific Ocean. The convection regime ultimately terminates in phase 8 , and the cycle repeats itself. Fire activity usually peaks over the MC during phases 5 to 7 as MJO induced subsidence inhibits precipitation over the region $[4,21]$, with burning over Sumatra being influenced by the phase of the MJO more than other regions in the MC [4]. Tropical cyclone (TC) activity in the SCS is a high-frequency phenomenon, which also induces subsidence over the MC and which was shown to have an important impact on forest fire occurrence and BBH transport [4,25].

The most recent El Nino related extreme episodes [4,16-19] occurred in 1997, 2006, 2009, and 2015. However, severe events can occur in any year, with Central Sumatra and its Riau province being less influenced by ENSO than other regions of the MC [4]. Indeed, one of the worst cases of biomass-burning haze occurred in 2013 [26], a year of neutral ENSO conditions. The Air Pollution Index (API) in Malaysia and the Pollution Standard Index (PSI) in Singapore reached hazardous levels in June 2013, and a state of emergency was declared in Malaysia [27]. The source was clear. Figure 1a,b show smoke being transported from Moderate Resolution Imaging Spectroradiometer (MODIS) active fire hotspots in Riau Provence, in Central Sumatra over Peninsular Malaysia on 19 June 2013. Resulting $\mathrm{PM}_{10}$ concentrations in June over the city of Muar in Malaysia (Figure 1c) largely exceeded the concentrations recorded for the other months from April to November by over a factor 
of four. Figure 1a also shows that the MODIS fire hotspots predominated over Riau as compared to the rest of the MC and that dry conditions prevailed over Sumatra and Peninsular Malaysia while low-pressure systems occurred over the South China Sea (SCS).
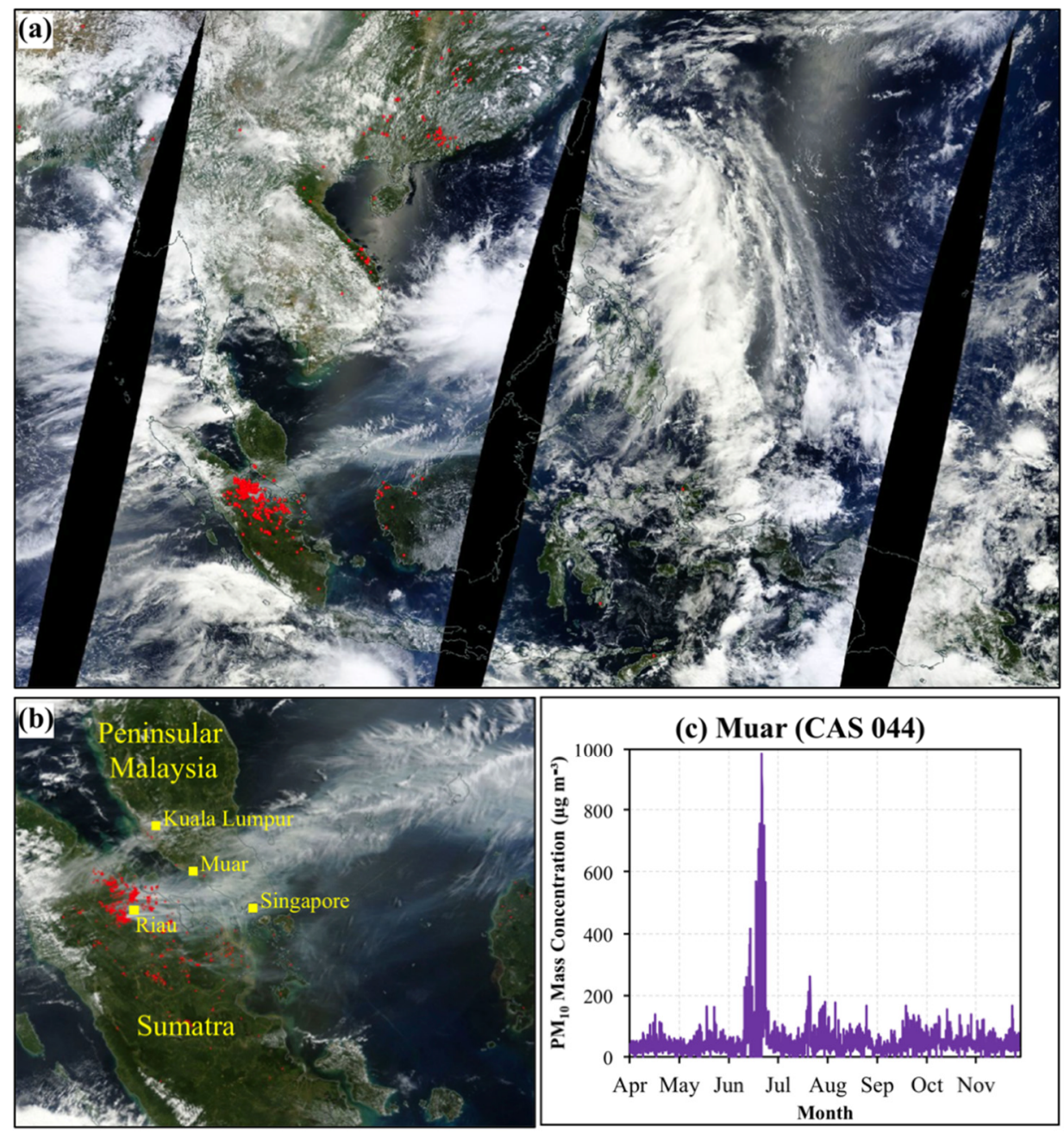

Figure 1. Haze over Sumatra and Peninsular Malaysia in June 2013. Satellite image from NASA's Moderate Resolution Imaging Spectroradiometer (MODIS) Terra satellite on 19 June 2013 over (a) Southeast Asia and (b) Sumatra and Peninsular Malaysia. The red dots correspond to the location of fire hotspots detected by MODIS. (c) Time series of observed $\mathrm{PM}_{10}$ mass concentrations (provided by the Malaysia Department of Environment (DOE Malaysia)) over Muar in Malaysia from April to November 2013.

While the most significant fire events in the MC usually occur between August and early October, small fire events in June are not uncommon [4]. However, the extreme magnitude of this June 2013 haze event is unique in the modern data record and thus has garnered significant attention. Previous studies on the June 2013 haze event mostly include statistical studies of the impacts of haze on air quality and health [27-29]. Vadrevu et al. [26] assessed the June 2013 episode based on satellite retrievals and showed that the aerosol optical thickness (AOT) for June 2013 was significantly higher than the previous years. Oozeer et al. [25] identified the convective mechanisms that uplifted the haze emissions from Sumatra to the upper troposphere and reported the influence of low-pressure systems over the SCS on the transport of these emissions over Peninsular Malaysia during the 2013 event. More recently, Koplitz et al. [30] investigated the effect of anomalous westerlies during the late phases of the MJO on the transport of haze the June 2013 episode. However, despite these efforts, to date, there has yet to be an overarching discussion of the overall meteorology that led to this unprecedented event. 
This study seeks to investigate the meteorological environment that prevailed during the haze episode, the parameters that have contributed to its intensification, and its peculiarity with regards to past extreme haze events. Here, we systematically examine the strong scale dependencies that interact to create such a significant event, starting with inter-seasonal ENSO [14,15], followed by the MJO [20-23] and TC activity over the SCS [31,32]. We also investigate, in detail, the relative influence of TC Bebinca over the SCS, and its interaction with the MJO, on the intensification of the June 2013 haze event. This is achieved by using the Weather Research and Forecasting model coupled with Chemistry (WRF-Chem) [33,34], which was shown to simulate well the distribution and evolution of biomass-burning aerosols, as well as their radiative impacts on the atmosphere [18,25,35-39].

This article is organized in the following manner. Section 2 provides an overview of the datasets and methods employed to study the aerosol and meteorological characteristics of the June 2013 haze event, as well as a description of the WRF-Chem model used. Section 3 discusses the aerosol and meteorological characteristics of the haze event and its peculiarity in relation to past extreme haze episodes. Section 4 discusses the evaluation of the model, the interaction between TC Bebinca and the MJO and their influence on the occurrence and intensification of the haze event. Finally, Section 5 concludes this article.

\section{Data and Methods}

\subsection{Episode Characteristics}

The study region in this paper covers the MC and the SCS and extends from $10^{\circ} \mathrm{S}$ to $10^{\circ} \mathrm{N}$ and $90^{\circ} \mathrm{E}$ to $150^{\circ} \mathrm{E}$, as shown in Figure 2a. We begin by investigating the aerosol and meteorological characteristics over the study region in June 2013, using satellite-derived datasets and meteorological indices, which are selected based on Reid et al. [4]. The combined MODIS Terra ( 10:30 LST) and Aqua ( 13:30 LST) $1 \mathrm{~km}$ daily active fire products are used to depict the overall fire activity during the June 2013 haze episode. Reid et al. [6] have pointed out that these data can only be considered semi-quantitatively since cloud cover can block the heat signature of fires. Fires in the MC are also sometimes too small to be detected by fire hotspot satellite products [40]. NASA MODIS col 6 Level 3 [41] aerosol optical thickness (AOT) at $550 \mathrm{~nm}$ are used to show the overall aerosol environment during the duration of the haze event in June 2013. Similar to fire data, AOT data in this region can be problematic due to high cirrus cover but nevertheless can track the location and relative intensity of individual events [6]. We then analyse the overall meteorological environment during the haze event using storm track, precipitation, and MJO characteristics data. The storm track data are obtained from the Unisys Weather hurricane archive database (weather.unisys.com/hurricane). Precipitation data are obtained from the high-resolution Climate Prediction Center MORPHing technique product (CMORPH) [42] for which the 3-h interval and $0.25^{\circ}$ resolution data are used in our analysis. CMORPH data are used as it best represents the temporal and spatial patterns of precipitation in the MC [43-46]. Finally, the MJO characteristics are analysed using the Wheeler and Hendon [47] product of the MJO phase and amplitude, available on the MJO page of the Bureau of Meteorology website (http://www.bom.gov.au/climate/mjo/).

We also use historical fire count, precipitation, and ENSO and MJO conditions data to investigate the peculiarity of the June 2013 haze event with regards to past extreme haze events in terms of its timing, ENSO and MJO conditions and fire count ratios. The MODIS Terra MOD14CM1 [48] and Aqua MYD14CM1 [49] 1 degree gridded monthly active fire products are used for the temporal analysis of fire activity over regions of interest in the MC for the years 2000-2015, for which a complete record exists [50,51]. The multivariate indices of Wolter and Timlin [52] and Wheeler and Hendon [47] are used for the temporal analysis of ENSO and MJO, respectively. The Multivariate ENSO Index (MEI) is a measure of the ENSO signal, which is based on six observed variables over the tropical Pacific, namely, sea-level pressure, surface zonal and meridional wind components, sea surface temperature, surface air temperature, and cloudiness [52]. Monthly MEI data from the year 1950 onwards can be 
obtained from the MEI page on the National Oceanic and Atmospheric Administration (NOAA) website (https://www.esrl.noaa.gov/psd/enso/mei/table.html). Historical CMORPH precipitation data for the month of June are used to investigate the influence of ENSO and MJO conditions on local weather.
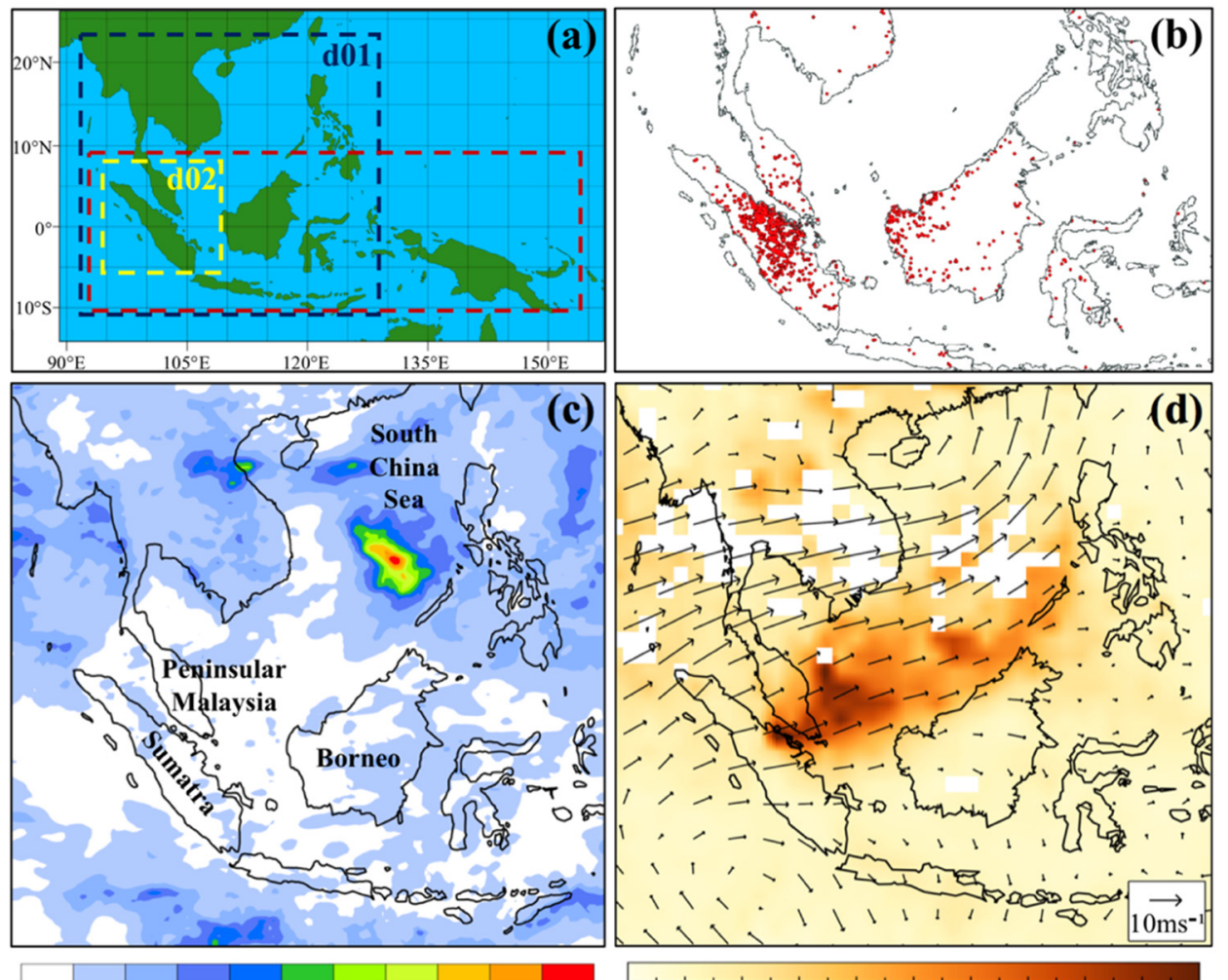

$\begin{array}{llllllllll}2 & 10 & 20 & 30 & 40 & 50 & 60 & 70 & 80 & 90\end{array}$ CMORPH Precipitation ( $\mathrm{mm} / \mathrm{day})$

$\begin{array}{llllllllllll}0.0 & 0.2 & 0.4 & 0.5 & 0.7 & 0.9 & 1.1 & 1.3 & 1.4 & 1.6 & 1.8\end{array}$ MODIS AOT $(550 \mathrm{~nm})$

Figure 2. Overview of the aerosol and meteorological environment over the study region from 17 to 25 June 2013. (a) WRF-Chem model domain (dark blue) and nest d02 (yellow), and the Maritime Continent (MC) (red). (b) MODIS Terra and Aqua active fire hotspot detections (red dots). (c) Climate Prediction Center MORPHing technique product (CMORPH) average daily precipitation. (d) MODIS aerosol optical thickness (AOT) at $550 \mathrm{~nm}$ overlaid by average surface winds from the WRF-Chem simulations used in this study.

\subsection{Model Setup}

The WRF-Chem model [33,34] is an online-coupled regional meteorological model that can simultaneously simulate weather, aerosol life cycle, aerosol-cloud-radiation interactions, and gas-phase chemistry. The selection of the model chemistry settings for the simulations in this study is based on Sessions et al. [53], Wang et al. [18], and Ge et al. [39], which all use the Fire Locating and Modeling of Burning Emissions (FLAMBE) dataset to simulate the forest fire smoke emissions. The main model chemistry and physics settings are shown in Table 1. Sensitivity WRF simulations (plots not shown here) were previously run with three cumulus parameterization schemes, namely, Betts-Miller-Janjic (BMJ) [54,55], Kain-Fritsch (KF) [56] and Grell 3D (G3D) cumulus scheme [57] over the model domain for the same study period. In summary, the BMJ scheme showed the best agreement to CMORPH data, and hence, all WRF-Chem simulations for this episode are run with BMJ, which is consistent with a recent study by Ge et al. [58] for the case of September 2011 in the Maritime Continent. Pennelly et al. [59] also report that BMJ simulates precipitation with better accuracy than KF and G3D at $30 \mathrm{~km}$ grid resolution. The overall model configuration is outlined below.

The model domain and nest used in this study are presented in Figure 2a. Domain d01 contains 160 $\times 15027 \mathrm{~km}$ grid points and serves to capture the large-scale dynamics and smoke transport over the 
study region. The nest d02 contains $172 \times 1729 \mathrm{~km}$ grid points and is used to investigate the presence of subsidence and its influence on forest fire occurrence over Sumatra. The model consists of 50 vertical sigma levels with about 12 layers concentrated in the lowest $1 \mathrm{~km}$ of the atmosphere and a model top set at $50 \mathrm{hPa}$. The initial and boundary meteorological conditions are provided by the European Centre for Medium-range Weather Forecast (ECMWF) ERA-Interim analyses [60] with a resolution of $0.7^{\circ}$ at $6 \mathrm{~h}$ intervals. Analysis nudging is also used to nudge the model towards the ERA-Interim analyses. The four nudged fields are the $u$ and $v$ horizontal wind components, temperature and specific humidity, while a nudging coefficient of $0.0003 \mathrm{~s}^{-1}$, corresponding to a timescale of $1 \mathrm{~h}$, is used for the present simulations.

Table 1. Model physics and chemistry.

\begin{tabular}{cc}
\hline \multicolumn{2}{c}{ Model Physics } \\
\hline Microphysics & Lin et al. [61] \\
Longwave radiation & RRTMG [62] \\
Shortwave radiation & RRTMG [63] \\
Land surface model & NOAH [64] \\
Planetary boundary layer & MYJ [65,66] \\
Cumulus & BMJ [54,55] \\
\hline Model Chemistry & \\
\hline Gas mechanism & RADM2 [67] \\
Inorganic aerosol mechanism & MADE [68] \\
Organic aerosol mechanism & SORGAM [69] \\
\hline
\end{tabular}

The FLAMBE database, which provides the smoke emission flux $\left(\mathrm{kg} \mathrm{h}^{-1}\right)$ for each fire pixel detected by MODIS [3], is used to specify the smoke emission rate in the simulations based on the parameterizations described by Reid et al. [3] and Wang et al. [18]. The FLAMBE smoke emission values were tripled before being integrated into the simulations since FLAMBE emissions have a low bias over the study region $[3,70,71]$ and a tripling of the FLAMBE emissions is recommended to remove the bulk of that bias over the study region [3]. The emissions injection height is set at $0.8 \mathrm{~km}$ based on the sensitivity studies done by Wang et al. [18]. It is important to note that since the focus of this study is the transport of smoke particles, background aerosols and aerosol radiative feedback are not included in the simulation. The simulations are initialized at 00UTC on 14 June 2013 and end at 00UTC on 27 June 2013. The FLAMBE emissions are updated for each day of the simulation, and the first 3 days of the run are considered as spin-up.

\subsection{Model Evaluation}

The model performance is evaluated in terms of its ability to reproduce the monsoonal precipitation and meteorological environment, as well as aerosol transport, over the study region before analysis. Accumulated precipitation from the model is evaluated with CMORPH data while $10 \mathrm{~m}$ wind speed and $2 \mathrm{~m}$ temperature are evaluated with measurements from ground stations over Peninsular Malaysia, operated by the Malaysia Department of Environment (DOE Malaysia). Measurements from 4 of the 52 ground stations, namely Johor (CAS 019; $\left.1.495^{\circ} \mathrm{N}, 103.736^{\circ} \mathrm{E}\right)$, Terengganu $\left(\mathrm{CAE} 034 ; 5.308^{\circ} \mathrm{N}\right.$, $\left.103.120^{\circ} \mathrm{E}\right)$, Perak (CAN 041; $\left.4.201^{\circ} \mathrm{N}, 100.664^{\circ} \mathrm{E}\right)$, and Kuala Lumpur (CAC 058; $3.212^{\circ} \mathrm{N}, 1^{101.682^{\circ}} \mathrm{E}$ ) are selected since they are sparsely located over the south, east, north, and west regions of Peninsular Malaysia. For this comparison, the grid index corresponding to the geographic location of each station is first determined. The model value of the required variables at the estimated grid index is then calculated by bi-linear interpolation from the surrounding four model grid points.

The smoke emissions produced by the model are evaluated by comparing the AOT and aerosol vertical profile with satellite data. The AOT at $550 \mathrm{~nm}$ simulated by the model is compared to retrievals from MODIS Terra satellite for 20 to 25 June 2013. The missing cells are first masked from 
the simulated AOT before performing a quantitative comparison with MODIS AOT. Vertical profiles from the Cloud-Aerosol Lidar with Orthogonal Polarisation (CALIOP) [72] instrument onboard the Cloud-Aerosol Lidar and Infrared Pathfinder Satellite Observation (CALIPSO) are used to evaluate the aerosol vertical profile simulated by the WRF-Chem simulations. The CALIOP Level 2 product at a horizontal and vertical resolution of $5 \mathrm{~km}$ and $60 \mathrm{~m}$, respectively, under $20 \mathrm{~km}$ is used in this study. The WRF-Chem simulated $\mathrm{PM}_{2.5}$ concentrations on 24 June 2013 at 07:00 UTC extracted along the corresponding CALIPSO track is compared with the CALIOP-derived extinction coefficient at $532 \mathrm{~nm}$.

\section{The June 2013 Haze Event}

\subsection{Overall Aerosol and Meteorological Environment during the June 2013 Haze Event}

The start of the biomass burning season in the MC generally starts in Riau Province, Central Sumatra, in June through early August [4]. While significant events existed in 2004 and 2005, the worst biomass burning haze episodes to affect air quality in major cities of the MC occurred in June 2013 [25-29]. Figure $2 b$ shows the MODIS fire hotspot detections over SEA during the study period. Fire activity was largely concentrated over the Riau region in Central Sumatra, while sparse hotspots occurred over Peninsular Malaysia and Borneo during the study period.

Reid et al. [4] gives an overview of the seasonal fire behaviour in the MC and notes that fire activity peaks over the MC as the Intertropical Convergence Zone (ITCZ) migrates northward during the summer monsoon. The southwest summer monsoon (SWM) season in SEA usually occurs from April to October, and prevailing surface winds generally blow from the southwest over the MC towards the monsoonal trough east of the Philippines [73-75]. The summer monsoonal trough extends from the West Pacific, through the Northern South China Sea, and further over land in PSA and into the Indian monsoon. However, part of the monsoonal trough precipitation is a result of cyclone activity rather than simple ITCZ convection, as was the case when tropical storm Bebinca occurred over the SCS. Figure 3a shows the storm tracks of TCs that prevailed in June 2013, including storm Bebinca. The CMORPH precipitation fields in Figure 2c for the 17 to 25 June 2013 event period show that precipitation was a maximum over the SCS and Eastern PSA while a distinct region of dryness prevailed over Sumatra, Peninsular Malaysia, and Western Borneo. In fact, as Figure 2 shows, Central Sumatra received less than $2 \mathrm{~mm}$ of rainfall per day. TC activity over the SCS and its associated induced dryness over the MC in June 2013 is further discussed in Section 4.2. In addition, the observed fire activity corresponded with high AOT values over the region, as can be seen in Figure 2d. AOT retrievals, at $550 \mathrm{~nm}$, of at least 1.8 can be observed over Central Sumatra and all across southern Peninsular Malaysia through Southern SCS. Figure $2 \mathrm{~d}$ also shows that smoke was transported all over the SCS by the prevailing southwesterlies and was eventually scavenged out by precipitation associated with tropical storm Bebinca. These winds were intensified as a result of TC activity over the SCS and the associated inflow arm enhancement, as discussed in Section 4.2.

Figure $3 \mathrm{~b}$ shows the Wheeler and Hendon [47] product of the MJO phase and amplitude for the months of May, June, and July 2013, while Figure 4 shows the CMORPH daily precipitation plots for the period 10 to 28 June 2013 over the region $30^{\circ} \mathrm{S}$ to $30^{\circ} \mathrm{N}$ and $30^{\circ} \mathrm{E}$ to $150^{\circ} \mathrm{W}$. Generally, MJO exists when amplitudes are higher than 1 and is deemed strong when amplitudes exceed 1.5. On 10 June, a weak phase 3 of the MJO prevailed, and precipitation occurred along the Eastern Indian Ocean, as shown in Figure 4a. Phase 4 of the MJO then prevailed until 14 June as convection and precipitation gradually shifted from Central MC towards Eastern MC, as shown in Figure 4b,c. Precipitation then increased over the Western Pacific Ocean as phase 5 of the MJO prevailed from 15 to 18 June. The occurrence of the haze episode over SPM between 17 and 25 June 2013 coincided with the dry phases of the MJO over the MC. The MJO transitioned from phase 5 to phase 6 from 18 to 19 June, and from phase 6 to 7 on 21 June. During these periods, maximum drying due to induced subsidence can be observed over the MC while precipitation due to TC Bebinca prevailed over the SCS, as shown in Figure 4f,g. The amplitude of the MJO was higher than 1 throughout the haze episode and exceeded 
1.5 from 23 June onwards. The MJO transitioned to phase 8 on 24 June marking the end of the dry phase over the MC. Figure $4 \mathrm{~h}-\mathrm{j}$ indeed show that precipitation gradually increased over the MC from 24 to 28 June. Similar mechanisms are also described in Reid et al. [24,76], showing the contribution of MJO related subsidence to increased biomass burning over the MC. Figure $3 \mathrm{~b}$ also shows that the strong MJO event of June 2013 is lagged and followed by weak MJO events with amplitudes of less than 1 from mid-May to the beginning of June and for most of July. This behaviour of the MJO was discussed by Napitu et al. [77] where the authors suggest that it is the result of vigorous cooling of the sea surface temperature (SST) by the previous strong MJO. The migration of the MJO from 17 to 25 June also coincided with the passage of tropical storm Bebinca over the SCS. This is further discussed in Section 4.2.
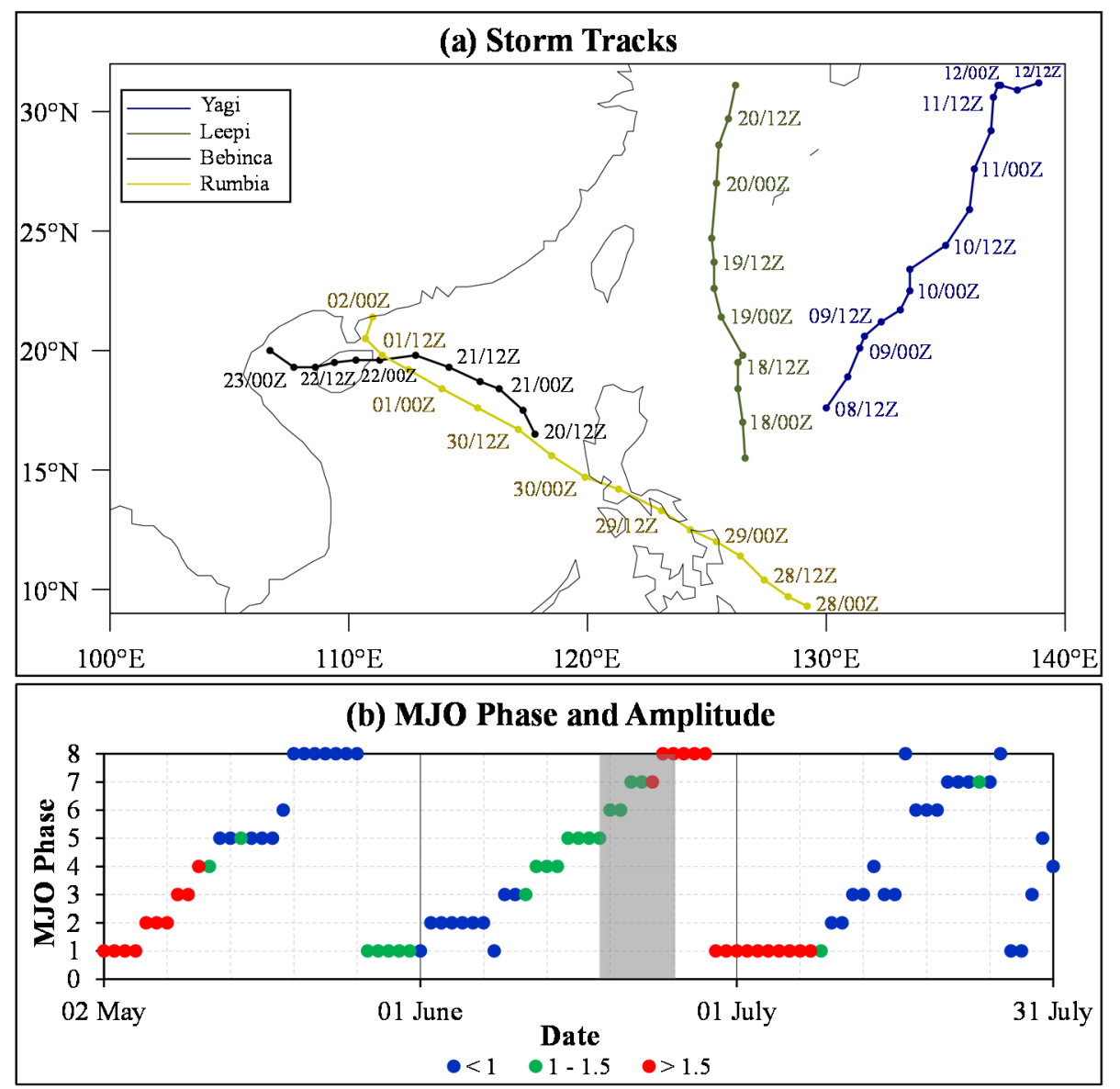

Figure 3. Storm tracks and Madden-Julian Oscillation (MJO) phase and amplitude. (a) Storm track of Yagi, Leepi, Bebinca, and Rumbia over the Western North Pacific (WNP) in June 2013 (http://www.weather.unisys.com/hurricane/w_pacific/2013/). The dates and times for each storm are also included. (b) Wheeler index of MJO phase and colour coded amplitude for May-July 2013, based on [76], where amplitudes greater than 1 and 1.5 are considered as significant and strong, respectively. The grey shaded area represents the period 18-25 June when the haze episode occurred. 

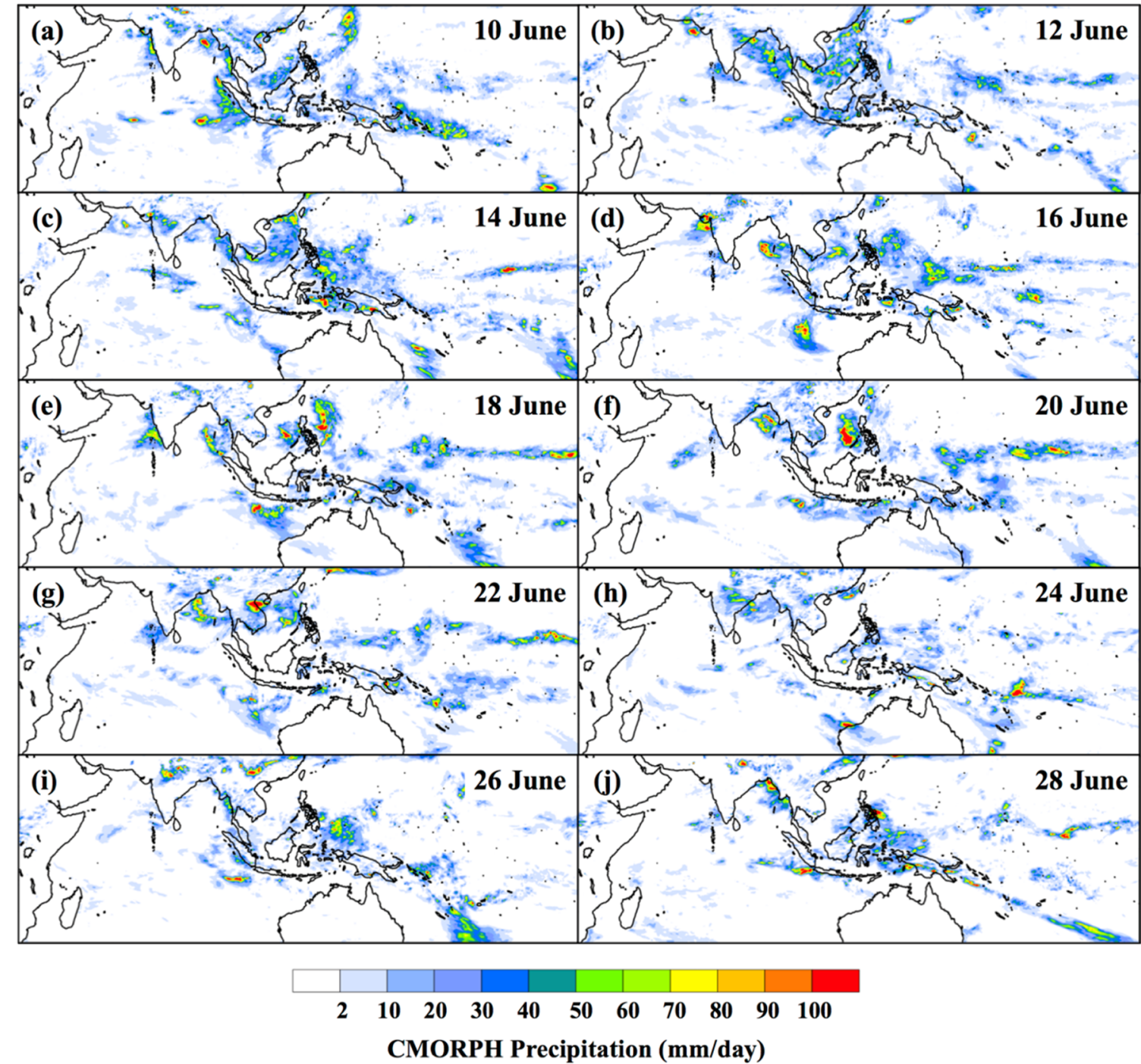

Figure 4. CMORPH daily precipitation over the region $30^{\circ} \mathrm{S}$ to $30^{\circ} \mathrm{N}$ and $30^{\circ} \mathrm{E}$ to $150^{\circ} \mathrm{W}$. for the period 10-28 June 2013 (a-j).

\subsection{3 in Context: Time-Series of Fire, ENSO, and MJO Characteristics}

The MEI time-series for the years 1980 to 2016 is shown in Figure 5a. Also included are markers that represent major haze episodes that occurred during that time period. Red markers represent episodes that occurred during ENSO warm phases while the yellow marker represents the June 2013 episode. As highlighted by Reid et al. [4], interannual fire variability is highly correlated to the ENSO warm phase, which can be observed in Figure 5a. The worst episodes occurred in 1982-1983, 1997-1998, and $2015[19,78]$ and the peak MEI values during these three episodes were 2.909, 3.038, and 2.527, respectively. Typically, El Nino events correspond to MEI values of greater than 0.5. Interestingly, the June 2013 haze episode, which is classified as one of the worst haze episodes in the region [27], occurred when neutral ENSO conditions prevailed. The MEI value during that month was -0.144 . In contrast, all major red marked haze episodes occurred when warm conditions prevailed. 

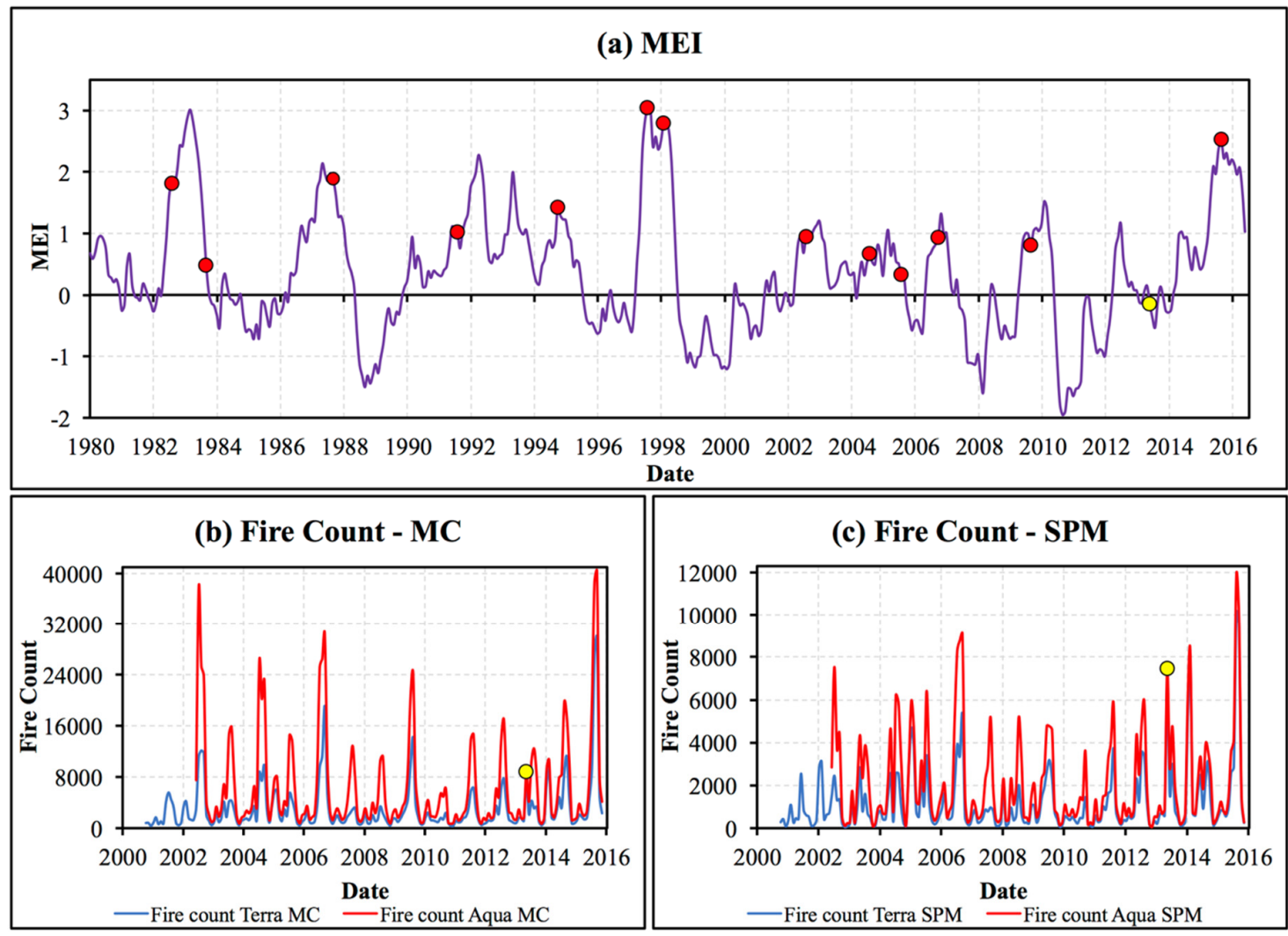

Figure 5. Time series data for the El Nino/Southern Oscillation (ENSO), fire over the Maritime Continent (MC) and MJO. (a) Multivariate ENSO Index (MEI) for 1980-2016. The red markers correspond to haze episodes that occurred when El-Nino conditions prevailed, from left to right, August-September 1982, September 1983, September 1987, August-September 1991, August-October 1994, August-October 1997, February-May 1998 [78], August-September 2002 [79], August 2004 [1], August 2005 [80], September-October 2006 [18], September 2009 [81], and September-October 2015 [19]. The yellow markers in (a-c) represent the June 2013 episode. (b) Monthly MODIS fire count for the MC from 2000-2015. (c) Monthly MODIS fire count for Sumatra and Peninsular Malaysia (SPM) for 2000-2015.

The inter-annual MODIS fire counts are also compared to show that the occurrence of the intense haze episode of June 2013 was indeed anomalous. While short pulses of fire activity over Central Sumatra in June are not new [4], major fire episodes usually occur between August and October, as can be seen in Figure 5a. Figure 5b shows the Aqua and Terra MODIS fire counts for the years 2000 to 2015 for the MC. Since neutral ENSO conditions prevailed in June 2013, as expected, the overall fire count in June 2013 ranked low as compared to fire counts for the months of August to October for the years 2002, 2004, 2006, 2009, 2014, and 2015, which were all El Nino years. However, the fire count for June 2013 was comparable to the fire counts for the bulk burning months in 2003, 2005, 2007, 2008, 2010, 2011, which were non-El Nino years. More interestingly, the fire count over Sumatra and Peninsular Malaysia (SPM) in June 2013 was comparable to the El Nino correlated episodes of 2002 and 2006, as shown in Figure 5c. While the fire count during the burning season in 2015 over SPM was substantially higher than that of June 2013, it is clear that the June 2013 episode has one of the highest fire counts recorded by MODIS satellites over SPM. The MODIS fire count over the MC and SPM in June for the years 2001-2015 are shown in Figure 5b. While bearing in mind that MODIS fire products may only be considered semi-quantitatively, it is important to note that the fire counts recorded by both Aqua and Terra over the MC and SPM for the month of June were higher in 2013 than for any other year since both satellites came into operation. In fact, the average fire count over SPM recorded by Aqua and Terra for the month of June since they came into operation are 2745 and 1692, respectively. In contrast, for June 2013, Aqua and Terra fire counts over SPM were 7453 and 6928, respectively. In addition, a 
ratio of fire count for SPM to MC, for the years 2001-2015, shows that the highest recorded ratio of 0.89 occurred in June 2013. Therefore, fire activity over SPM in June 2013 was indeed anomalous for that period of the year under the prevailing neutral ENSO conditions.

Figure 6 shows the time series data for ENSO, precipitation, fire count, and the MJO in June. While ENSO is a good indicator of seasonal burning, it cannot explain all dry spells and corresponding burning episodes. Figure $6 \mathrm{~b}$ shows that intense fire episodes over the MC occurred in June for the years 2003, 2004, 2005, 2009, and 2012. The average ratio of fire count for SPM to MC from both Aqua and Terra satellites was at least 0.60 in June for these years. The MEI values in June for the years 2001-2015 and the mean CMORPH daily precipitation rates over SPM in June for the years 2003-2015 are shown in Figure 6a. The average precipitation rate over SPM in June for that period was $1.6 \mathrm{~mm}$ day $^{-1}$. In contrast, the precipitation rates in June for the years $2003\left(0.9 \mathrm{~mm} \mathrm{day}^{-1}\right), 2004(1.3 \mathrm{~mm}$ day $\left.^{-1}\right), 2009\left(1.4 \mathrm{~mm} \mathrm{day}^{-1}\right), 2012\left(1.2 \mathrm{~mm} \mathrm{day}^{-1}\right)$, and $2013\left(1.5 \mathrm{~mm} \mathrm{day}^{-1}\right)$ were all lower than the average, except for the year 2005 (1.8 $\left.\mathrm{mm} \mathrm{day}^{-1}\right)$. In 2003, 2004, 2005, and 2013, neutral conditions prevailed while the MEI values for 2009 and 2012 were 0.880 and 0.941 , respectively. Therefore, in June 2009 and 2012 years, the low precipitation rates can be largely explained by the prevailing ENSO conditions, as shown in Figure 6a. In June 2003 and 2004, the daily precipitation rates were particularly low at 0.9 and $1.3 \mathrm{~mm} \mathrm{day}^{-1}$, respectively, despite the prevailing neutral ENSO conditions. Positive El Nino Modoki conditions reported by Reid et al. [4] during these two years could have contributed to subsidence over the MC. Positive Modoki events represent a phenomenon of positive SST anomalies over the Central Pacific, which results in increased surface pressure over the MC [82]. In addition, MODIS on both Aqua and Terra recorded a higher fire count in 2003 and 2004 than 2009 and 2012 for both MC and SPM. The only exception was the MODIS Terra fire count for the MC in June 2004, which was comparable to that of June 2012. This shows that while ENSO is a good indicator of seasonal burning, the intensity of burning activity does not only depend on ENSO conditions. Comparing June 2013 to June 2003 and 2004, the daily precipitation rates over SPM were only slightly higher in 2013 at $1.5 \mathrm{~mm} \mathrm{day}^{-1}$. However, it needs to be reiterated that, interestingly, the highest fire count in June was recorded in 2013 for the period 2001-2015. This indicates that the days during which the haze episode occurred in June 2013 were much drier than the rest of the month since very dry conditions must have prevailed to sustain the intense burning episode of June 2013.

The MJO phase and amplitude in June for the years 2003, 2004, 2005, and 2013 are compared in Figure $6 \mathrm{c}$ to further investigate the meteorological environment during the June months when high fire counts were recorded when neutral ENSO conditions prevailed. A transition to a new MJO cycle occurred in June 2003 as phases 8 and 1 were predominant during that time period. This shows that subsidence over the region during that period was not a result of the MJO cycle. In contrast, phases 2 and 3 dominated June in 2005 at amplitudes of less than 1 showing that a weak MJO prevailed during that period. More importantly, it can be seen that a complete MJO cycle occurred in 2004 and 2013. As mentioned in Section 4.1, the strong MJO event of June 2013 coincided with the occurrence of the haze episode over SPM. While amplitudes of higher than 1 prevailed in June 2013, the MJO event of June 2004 was dominated by amplitudes of lower than 1 until the end of the month when amplitudes of higher than 1.5 prevailed during phase 7. Therefore, the stronger MJO event of 2013 could have contributed to the much higher fire count as compared to June 2004. 

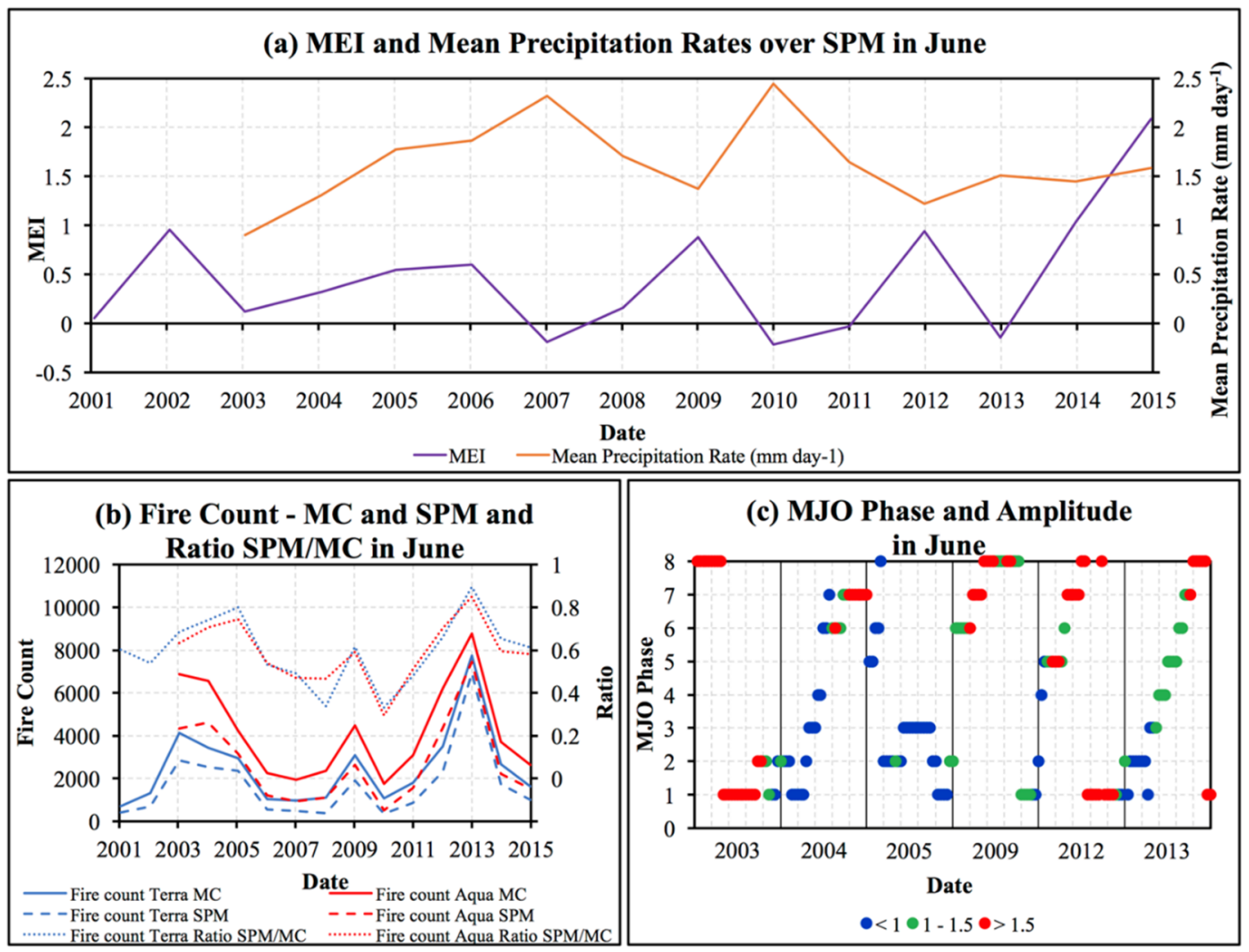

Figure 6. Time series data for ENSO, precipitation, fire over the MC and SPM, and MJO in June. (a) Multivariate ENSO Index (MEI) for 2001-2015 and mean CMORPH daily precipitation rate (mm day ${ }^{-1}$ ) over SPM for the years 2003-2015. SPM for CMORPH precipitation rates include data cells over the region $-6^{\circ} \mathrm{S}$ to $7^{\circ} \mathrm{N}$ and $95^{\circ} \mathrm{E}$ to $107^{\circ} \mathrm{E}$. (b) Monthly MODIS fire count for the MC and SPM, and ratio of MODIS fire count over SPM to that over MC from 2001-2015. (c) Wheeler index of MJO phase and colour coded amplitude for the years 2003, 2004, 2005, 2009, 2012, and 2013.

\section{Results and Discussion}

\subsection{Model Evaluation Results}

Overall, WRF-Chem successfully captures the location and magnitude of precipitation over the northern domain area but with a slight westward phase shift in intensity, as shown in Figure 7a,b. Since the model is nudged to ERA-Interim analyses, a plot of ERA-Interim accumulated precipitation is included in Figure 7c. While ERA-Interim successfully captures the location of precipitation, it fails to capture the regions of high precipitation over the SCS as compared to CMORPH and WRF-Chem. This indicates that the BMJ cumulus parameterization in WRF-Chem is able to resolve convection over the model domain. Pennelly et al. [59] reported a similar phase shift in intensity to that observed in Figure $7 \mathrm{~b}$, which occurs with simulations run with BMJ cumulus parameterization at $30 \mathrm{~km}$ resolution but not $15 \mathrm{~km}$ resolution. The shift in precipitation intensity can, therefore, be attributed to the relatively coarse grid resolution of $27 \mathrm{~km}$ used in this study. CMORPH, WRF-Chem, and ERA-Interim all show that while precipitation prevailed over the northern half of the domain, a distinct region of dryness can be observed over Peninsular Malaysia, Sumatra, and Borneo. This precipitation pattern is indeed characteristic of the SWM season [73-75], which was described in Section 3.1. 

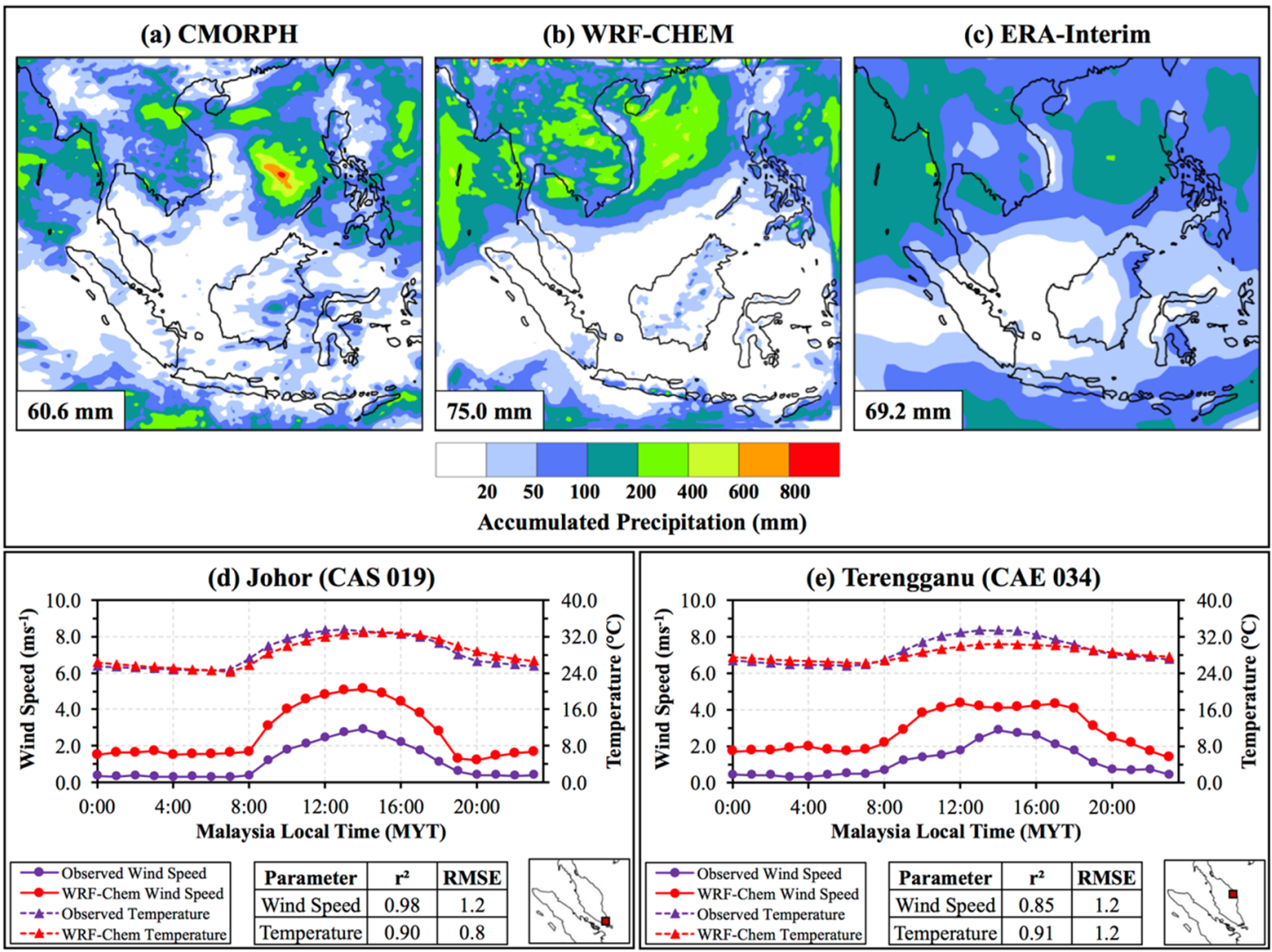

(e) Terengganu (CAE 034)
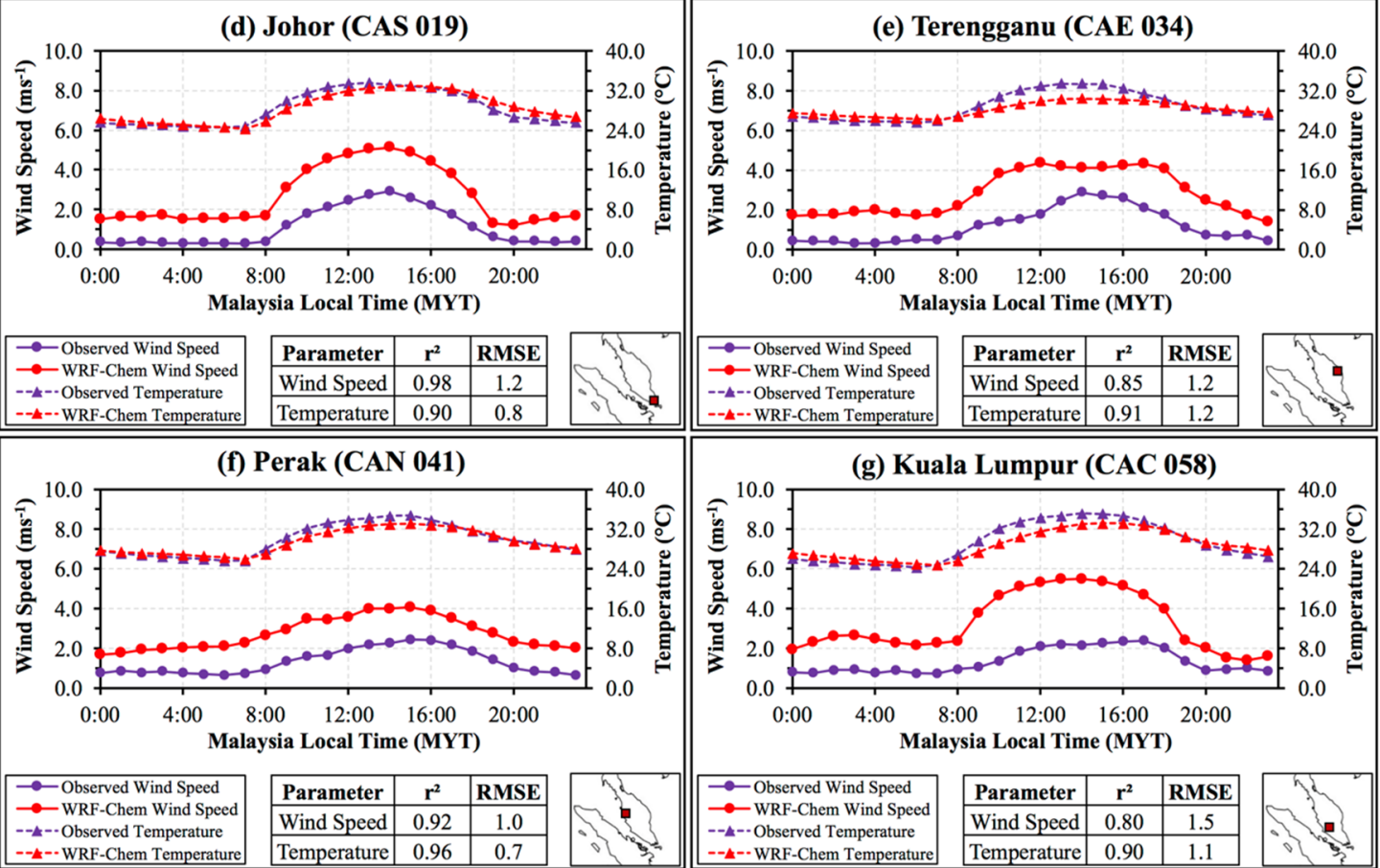

Figure 7. Meteorological evaluation for the period 17 to 25 June 2013. Co-located accumulated precipitation (mm) from (a) CMORPH and (b) WRF-Chem and (c) ERA-Interim. Comparison of hourly averaged observed and model-simulated $10 \mathrm{~m}$ wind speed $\left(\mathrm{m} \mathrm{s}^{-1}\right)$ and $2 \mathrm{~m}$ temperature $\left({ }^{\circ} \mathrm{C}\right)$ at $(\mathbf{d})$ Johor, (e) Terengganu, (f) Perak, and (g) Kuala Lumpur. The solid red square on each inset map shows the location of each corresponding site.

Figure $7 \mathrm{~d}-\mathrm{g}$ show the comparison between hourly averaged $10 \mathrm{~m}$ wind speed and $2 \mathrm{~m}$ temperature recorded at the selected 4 four ground stations operated by DOE Malaysia and the model. The model reproduced the $10 \mathrm{~m}$ wind speed and $2 \mathrm{~m}$ temperature diurnal variation successfully at all four stations for the period of 17 to 25 June 2013. However, WRF-Chem overestimates the model wind speed at all four stations. WRF was found to have the tendency to overestimate wind speed [83-85], particularly in areas of complex terrain where topographic features cannot be explicitly considered by the coarse resolution of the model. This implies that smoother orography underestimates the terrain roughness, which eventually leads to an excess of wind speed [86]. Therefore, the overestimation of the $10 \mathrm{~m}$ wind speed in this study is likely due to the relatively coarse $27 \mathrm{~km}$ resolution of the domain. Nevertheless, for $10 \mathrm{~m}$ wind speed, the highest correlation, $\mathrm{r}^{2}=0.98$, was observed at the Johor station while the lowest root mean square error (RMSE), RMSE $=1.0 \mathrm{~m} \mathrm{~s}^{-1}$ was recorded at Perak. The highest 
correlation and lowest RMSE for $2 \mathrm{~m}$ temperature were also observed at Perak and were $\mathrm{r}^{2}=0.96$ and RMSE $=0.7^{\circ} \mathrm{C}$, respectively. The correlations and RMSEs for each station are shown at the bottom of each figure.

The model succeeds at producing similar patterns and magnitudes of AOT over the MC, as shown in Figure 8a,b. However, the MODIS AOT retrieval in Figure 8a is an aggregation of 6 days of individual retrievals from MODIS Terra, which contain missing cells of AOT data for the model domain, particularly for very high AOT smoke in which the retrieval fails. Huang et al. [87] and Reid et al. [6] advise caution when evaluating AOT maps in the study region, where cirrus contamination in the MODIS products can also increase the baseline AOT throughout the region. This explains the relatively low AOT values retrieved from MODIS Terra as compared to the model. Observed AOTs over the domain are at least 2.4 while over the corresponding regions, the WRF-Chem simulations produce AOTs of at least 3 . However, the spatial correlation between the masked simulated AOT and MODIS AOT is as high as 0.71 , showing that the model successfully captures the smoke northeasterly smoke transport pattern towards the SCS. The model also successfully captures the variations in plume height as shown by the plume peaks between latitudes $1^{\circ} \mathrm{S}$ and $2^{\circ} \mathrm{N}$, and $4^{\circ} \mathrm{N}$, and $7^{\circ} \mathrm{N}$ in Figure $8 \mathrm{c}$, d. The plume peaks in these two regions reached $3 \mathrm{~km}$ in height. Both plots also show that the smoke particles were confined to within $3 \mathrm{~km}$ in height along the CALIPSO track.

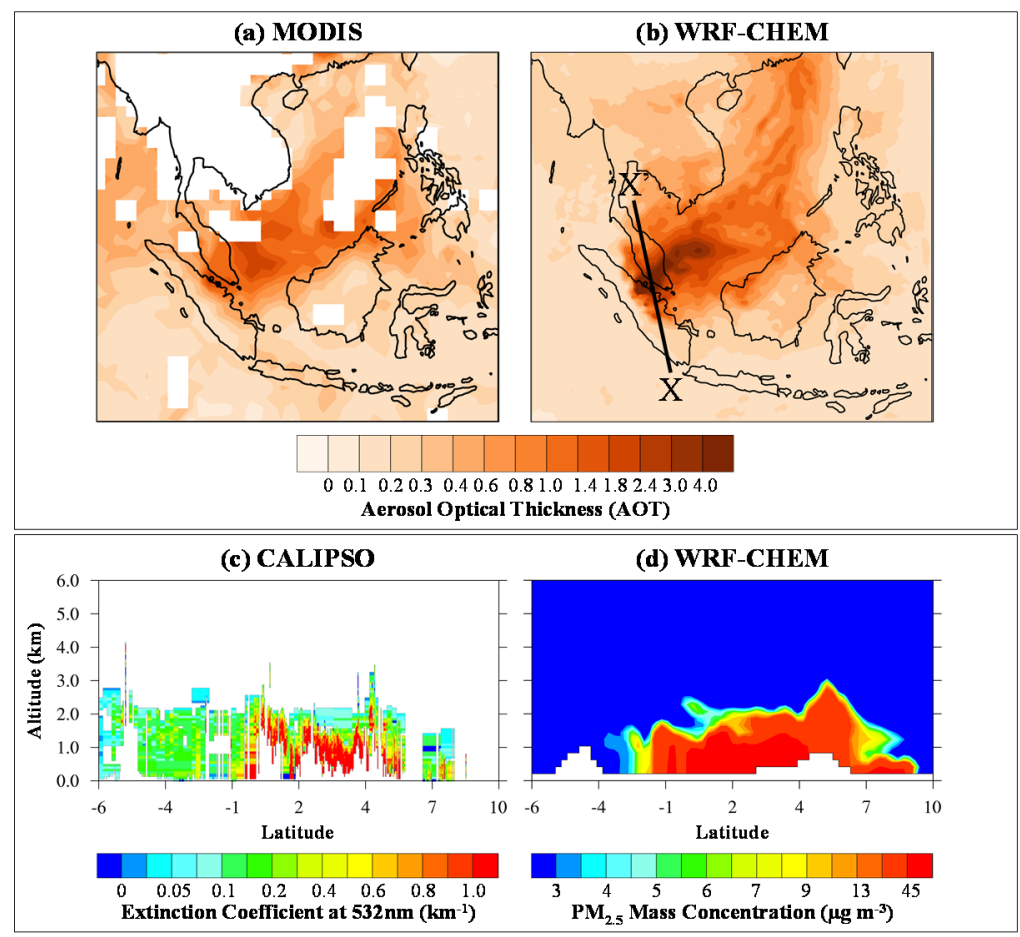

Figure 8. Aerosol optical thickness (AOT) at $550 \mathrm{~nm}$, from 20 to 25 June 2013 over the MC from (a) MODIS Terra and (b) WRF-Chem simulations. Also, the comparison of (c) CALIOP-derived vertical profile of extinction coefficient at $532 \mathrm{~nm}$ with (d) the WRF-Chem simulated vertical profile of $\mathrm{PM}_{2.5}$ smoke concentration along the corresponding portion of the CALIPSO ground track on 24 June 2013. The ground track is indicated by the line $X X^{\prime}$ on $(\mathbf{b})$.

\subsection{Combined Effect of Tropical Cyclone Bebinca and MJO}

During the summer monsoon, as the ITCZ migrates northwards, southwesterlies tend to prevail over the western MC and the SCS. Furthermore, the Western North Pacific (WNP) is the most active basin of tropical cyclogenesis [88], and 80\% of the TCs develop within or in the surroundings of the ITCZ, where low-level convergence occurs between the trade easterlies and the southwesterlies [89,90]. In 2013, the TC season in the WNP was marked by an above average genesis of TCs and was characterized 
by an early active TC season in June [32]. In fact, four TCs were generated in June 2013, which is twice the climatological average of 1.8 TCs. These four TCs, namely Tropical Storm Yagi (8-12 June), Tropical Storm Leepi (17-20 June), Tropical Storm Bebinca (20-23 June), and Typhoon Rumbia (28 June-2 July), are shown in Figure 3a. Bebinca, which coincided with the extreme haze event over Sumatra, Singapore, and Malaysia, began to develop on 18 June and rapidly intensified into a Tropical Depression (TD) migrating northwards over the SCS. By 21 June Bebinca had intensified into a Tropical Storm (TS) and started migrating westwards towards PSA, and maximum wind speeds of $18 \mathrm{~m} \mathrm{~s}^{-1}$ were recorded. By 24 June, Bebinca had lost strength as it made landfall over PSA. More details about the mentioned storms can be found in the Joint Typhoon Warning Center Annual Tropical Cyclone Report for 2013 (http://www.usno.navy.mil/NOOC/nmfc-ph/RSS/jtwc/atcr/2013atcr.pdf).

The increase in fire activity in the southern MC and transport of smoke over the SCS as TCs transit the SCS has been reported by Reid et al. [4,24]. Wang et al. [18] also showed how cyclone Xangsane enhanced southwesterly winds and induced large scale subsidence over the MC, which contributed to fire propagation over Kalimantan and Sumatra in October 2006. However, these events occurred when TCs are climatologically more prevalent in the South China Sea/Philippines region. In June, the storm tracks are typically further north. In June 2013, however, TCs were abnormally south. Weather in the MC was influenced by an intensification of the low-pressure belt of the northern ITCZ, which drew stronger winds from the Indian Ocean towards the northeast [25]. This intensification was in fact Bebinca. The coevolution of Bebinca and the haze event is depicted in Figure 9, which shows MODIS images from the Terra and Aqua satellites for 17 to 26 June 2013, the corresponding WRF-Chem simulated daily averaged sea level pressure (SLP), and near-surface wind patterns, as well as daily averaged and vertically integrated $\mathrm{PM}_{2.5}$ concentrations (darker red plumes indicate higher concentrations of $\mathrm{PM}_{2.5}$ ). On 17 June, very few fire hotspots can be observed over the $\mathrm{MC}$ with westerlies and southwesterlies blowing over Sumatra and Peninsular Malaysia, as shown in Figure 9a,g. On 19 June, increased cloud cover can be observed over the SCS, as Bebinca gradually generated into a TD near $16^{\circ} \mathrm{N}$ and $115^{\circ}$ E over the SCS, while the reverse occurred over Sumatra and Peninsular Malaysia, as shown in Figure 9b. An increase in fire hotspots over Central Sumatra can also be observed, as well as smoke being transported in a northeasterly direction from the hotspots over Sumatra to Western Borneo and the SCS by enhanced monsoonal flow. The eastward motion of the emissions plume is aided by winds associated with the Sumatran low located near $5^{\circ} \mathrm{S}$ and $105^{\circ} \mathrm{E}$, as shown in Figure 9h,n, as well as the prevailing westerlies, which persist over Sumatra during the dry phase of the MJO over the MC.

By 21 June, cyclone Bebinca had intensified into a TS, as shown by increased cloud cover over the SCS in Figure 9c, and reduced SLP and stronger associated winds, as shown in Figure 9i. As Bebinca started moving westward toward PSA, relatively dry weather persisted over Central Sumatra, except for some scarce clouds associated with Bebinca. A high number of fire hotspots prevailed over Sumatra, as well as continued haze propagation over the MC. Despite the fact that part of the smoke seemed to be confined within the clouds in Figure 9c, a similar widespread smoke pattern is simulated by the model, as shown in Figure 9o. On 22 June, the intense TC Bebinca had already reached the east coast of PSA, and the winds over Sumatra and Peninsular Malaysia had shifted to higher flow in a north-northeasterly direction. This also resulted in a gradual shift in the plume flow from Sumatra, as shown in Figure 9p. In fact, the most intense and widespread emissions seem to have occurred between 21 and 22 June, as shown by Figure 9o,p. This period also corresponds to the period during which TC Bebinca was the strongest, as shown in Figure 9i,j. Figure 10 shows the vertical velocity over cross-sections $Y^{\prime} Y^{\prime}$ and $Z Z^{\prime}$, which are marked in Figure 9j, on 22 June. The wind fields for each cross-section were calculated from the horizontal velocity along that cross-section and 10 times the vertical velocity. The intensification and propagation of hotspots and emissions over Sumatra can be attributed to the large-scale subsidence and induced dryness due to cyclone Bebinca, as shown in Figure 10a. Deep convection can be observed between $15^{\circ} \mathrm{N}$ and $22^{\circ} \mathrm{N}$ resulting in large scale divergence near the upper troposphere. Air over Sumatra, near the equator, is, in turn, accelerated 
towards the convection centre of Bebinca through the inflow arm of the cyclone. Upper level winds are accelerated towards the equator where upper level convergence occurs, resulting in subsidence over Sumatra and the formation of a deep convective cell between the equator and $22^{\circ} \mathrm{N}$ along cross-section YY'. Orographic motion over the mountains of Sumatra can also be observed. The influence of dry air due to mountain flow on increased fire activity over Central Sumatra in June 2013 is discussed by Oozeer et al. [25].
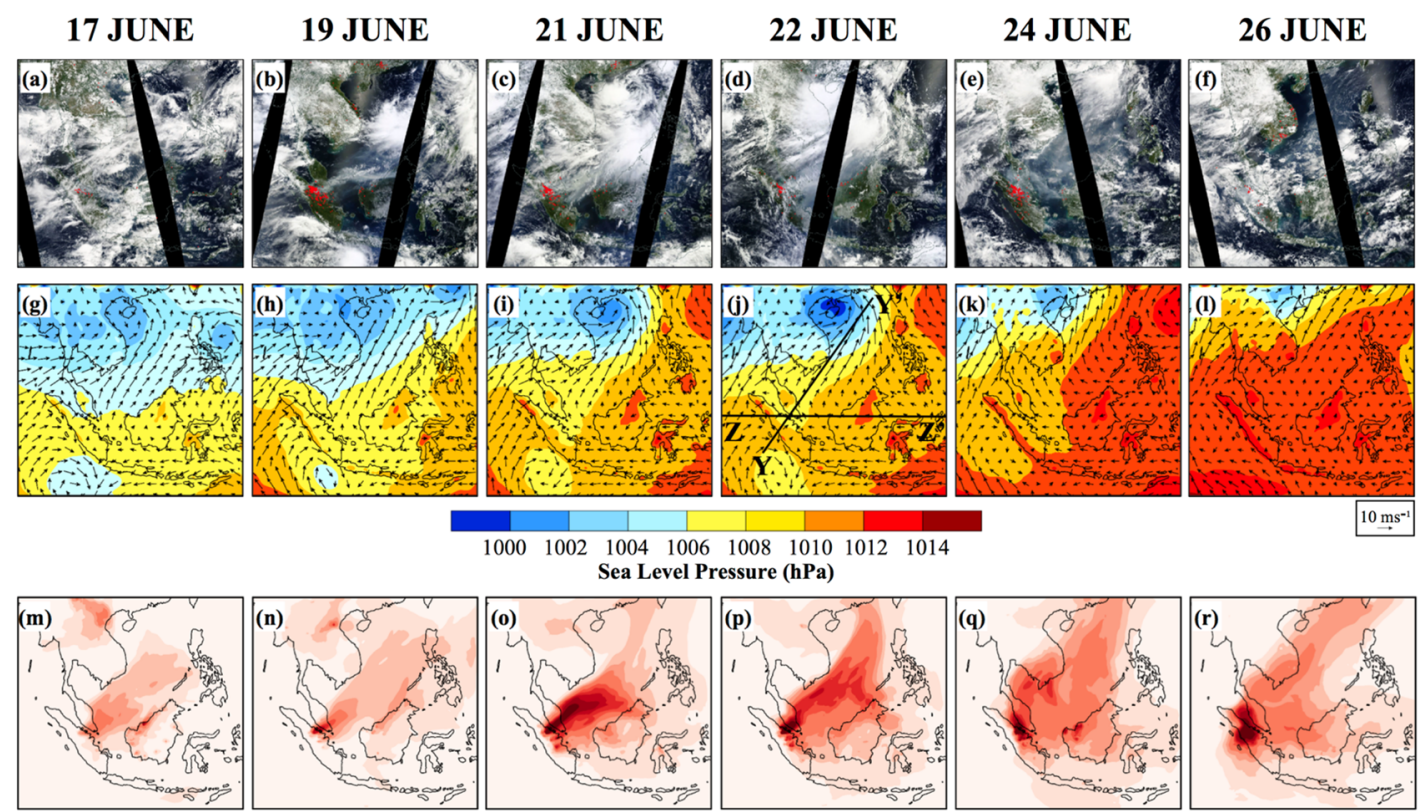

Figure 9. MODIS images from the Terra and Aqua satellites for days between 17 and 26 June 2013 (a-f). The red spots correspond to regions of fire hotspots. (g-l) The corresponding WRF-Chem simulated daily averaged SLP $(\mathrm{hPa})$ and near-surface wind fields $\left(\mathrm{m} \mathrm{s}^{-1}\right)$. $(\mathbf{m}-\mathbf{r})$ The daily averaged and vertically integrated $\mathrm{PM}_{2.5}$ concentration (darker red plumes indicate higher concentrations of $\mathrm{PM}_{2.5}$ ). The black lines over (j) represent cross-sections $Y^{\prime}{ }^{\prime}$ and $Z Z^{\prime}$.
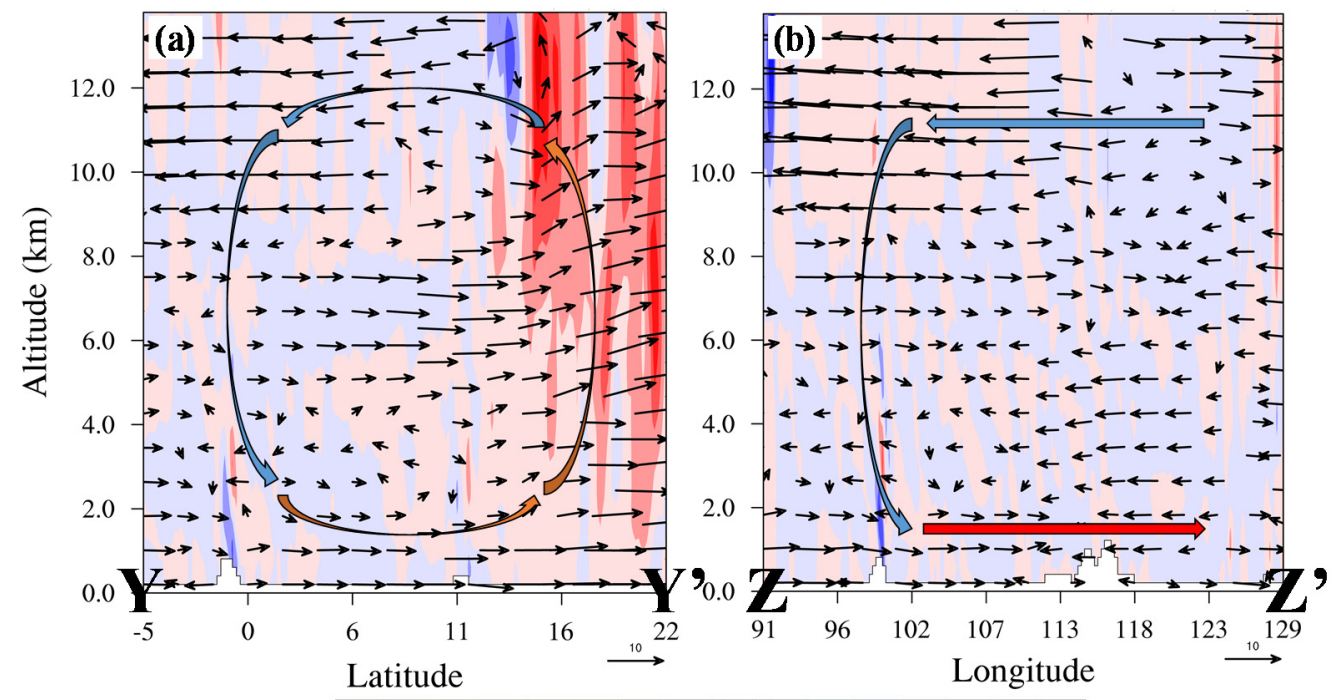

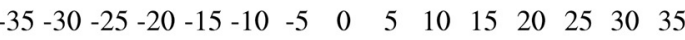
Vertical Wind Speed $\left(\mathrm{cms}^{-1}\right)$

Figure 10. Wind fields $\left(\mathrm{m} \mathrm{s}^{-1}\right)$ (arrows) and vertical wind speed $\left(\mathrm{cm} \mathrm{s}^{-1}\right)$ (shaded colours) on 22 June along (a) $\mathrm{YY}^{\prime}$ and (b) $Z Z^{\prime}$. The coloured red and blue arrows represent the overall convective cells that occur along each respective cross-section. 
To further investigate the proposed subsidence mechanisms induced by TC Bebinca over Riau, SLP and $700 \mathrm{hPa}$ geopotential height maps, as well as $700 \mathrm{hPa}$ geopotential height and surface relative humidity anomalies from the WRF-Chem simulations, are shown in Figure 11. The plots in Figure 11 were extracted from the model output for the nest d02. Figure 11a shows the daily averaged SLP for the period 17-26 June 2013, while Figure 11b shows the daily averaged geopotential height plots overlaid with the total fire hotspots for the same period. Figure 11a indicates that relatively high pressure prevailed over SPM during the period 17-26 June, where the minimum prevailing daily averaged SLP was as high as $1006 \mathrm{hPa}$. Relatively weak southwesterlies also prevailed over Riau during that period. While high pressure prevailed over the entire nest during the 17-26 June period, Figure $11 \mathrm{~b}$ shows that higher pressure particularly prevailed over the Riau region as compared to the rest of Sumatra. The daily averaged $700 \mathrm{hPa}$ geopotential height over Riau was at least $3136 \mathrm{~m}$. More importantly, Figure 11b shows that the fire hotspots detected by MODIS were concentrated over that region of higher $700 \mathrm{hPa}$ geopotential height over Sumatra. This indicates that the overall subsidence and higher pressure over Riau intensified the June 2013 fire episode. Figure 11c,d show the $700 \mathrm{hPa}$ geopotential height anomaly overlaid with $10 \mathrm{~m}$ wind anomaly vectors, and surface relative humidity anomaly, respectively, between the period 21-23 June and the remaining days of the 10-day period 17-26 June. These three days were selected since TC Bebinca reached maximum intensity between 21 and 23 June. Figure 11c shows that TC Bebinca induced a high-pressure system over the eastern part of the nest in addition to the prevailing high pressure conditions over the entire nest during the 10-day period. Indeed, a clockwise wind motion can be observed near the eastern coast of SPM while positive geopotential anomalies can be observed over the same region and over Peninsular Malaysia and northern Sumatra. This suggests that these regions of positive geopotential height anomalies might have had a "dam effect", which confined the bulk of the $\mathrm{PM}_{2.5}$ concentrations over SPM, as shown in Figure 9m-r. In addition, Figure 11d indicates that TC Bebinca induced more dryness over Riau as the surface relative humidity anomaly plot shows a decrease in relative humidity of at least $10 \%$. More importantly, the MODIS fire hotspots for the period 21-23 June shown in Figure 11d coincide exactly with the regions of negative surface relative humidity anomaly over Riau. This further shows the fire hotspots over Riau during the 21-23 June period were indeed the result of the dryness induced by Bebinca.

Figure $9 \mathrm{k}$ shows that cyclone Bebinca had lost in intensity by 24 June, but induced subsidence and dryness prevailed over Sumatra, and emissions were still strong on that day with the plume flowing in a northerly direction. By 26 June, Bebinca had weakened into a low-pressure system, and the subsidence over Sumatra had subsided, as shown by the increase in cloud cover in Figure 9f. Fire hotspots had also drastically reduced over Sumatra and so did the emissions as a result. The weakening of cyclone Bebinca marked the end of the haze episode over Peninsular Malaysia and Sumatra thus indicating a significant correlation between the intensification and propagation of forest fires and the transport of BBH over the MC due to TC activity over the SCS. More importantly, this shows that improving the ability to predict extreme TC episodes over the SCS can, in turn, help improve our ability to model and predict intense BBH episodes over the MC.

It is also important to note that the migration of the MJO discussed in Sections 3.1 and 3.2 coincided with the train of TC activity over the SCS and NWP in June 2013, as was the case in Reid et al. [24] during the Vasco Cruise in September 2011. Maloney and Hartmann [91] reported that the transit and departure of the MJO from the MC is often associated with an increase in TC formation in the region. The favourable conditions for TC formation set by the transit of the MJO in June 2013, which are growing eddies, strong surface convergence, and high sea surface temperatures [91], could have, therefore, contributed to the formation of the four TCs shown in Figure 3a. Two characteristics of the MJO-TC relationship for June 2013 are of note. Firstly, out of the four TCs, only Bebinca and Rumbia crossed the SCS while Yagi and Leepi migrated northwards over WNP, and the seesaw shift of the preferable cyclogenesis region discussed in Kim et al. [92] can be observed in June 2013. Usually, when the MJO related convection centre is located over the Indian Ocean, TCs tend to migrate eastward, 
and westward when the MJO convection centre occurs over the WNP. As can be seen in Figure 5, Yagi occurred during phases 2-4 of the MJO, Leepi occurred during phase 5, Bebinca occurred during phases 6-7, and Rumbia occurred during phase 8 . This leads to the second characteristic of the MJO-TC relationship over the MC in June 2013. The migration of Bebinca over the SCS coincided with the dry phases of the $\mathrm{MJO}$ over the $\mathrm{MC}$, and therefore, the combined subsidence due to Bebinca and the MJO lead to intense fire activity occurring over Central Sumatra. Figure 10b shows the cross-section ZZ' marked over Figure 9j. Low level westerlies and upper level easterlies can be observed along ZZ' with subsidence occurring throughout the cross-section over the $\mathrm{MC}$, especially between $96^{\circ} \mathrm{E}$ and $107^{\circ}$ E. The convective centre is not visible in Figure 10b since by phases $6-7$ of the MJO, convection occurs to the east of the model domain. It is also interesting to note that no major haze event occurred when Rumbia, which had intensified into a Category 1 Typhoon with maximum wind speeds of $36 \mathrm{~m}$ $\mathrm{s}^{-1}$ (twice as fast as Bebinca), migrated westwards over the SCS. This suggests that Rumbia related subsidence was not enough to suppress the MJO related convection over the MC. Rumbia coincided with phase 8 of the MJO when the MJO cycle was about to terminate over the Pacific and restart over the Indian Ocean. MJO amplitudes were higher than 1.5 from 23 June to 8 July. The uncharacteristically early and strong June 2013 event, therefore, occurred as a result of the combined subsidence from Bebinca and the MJO.
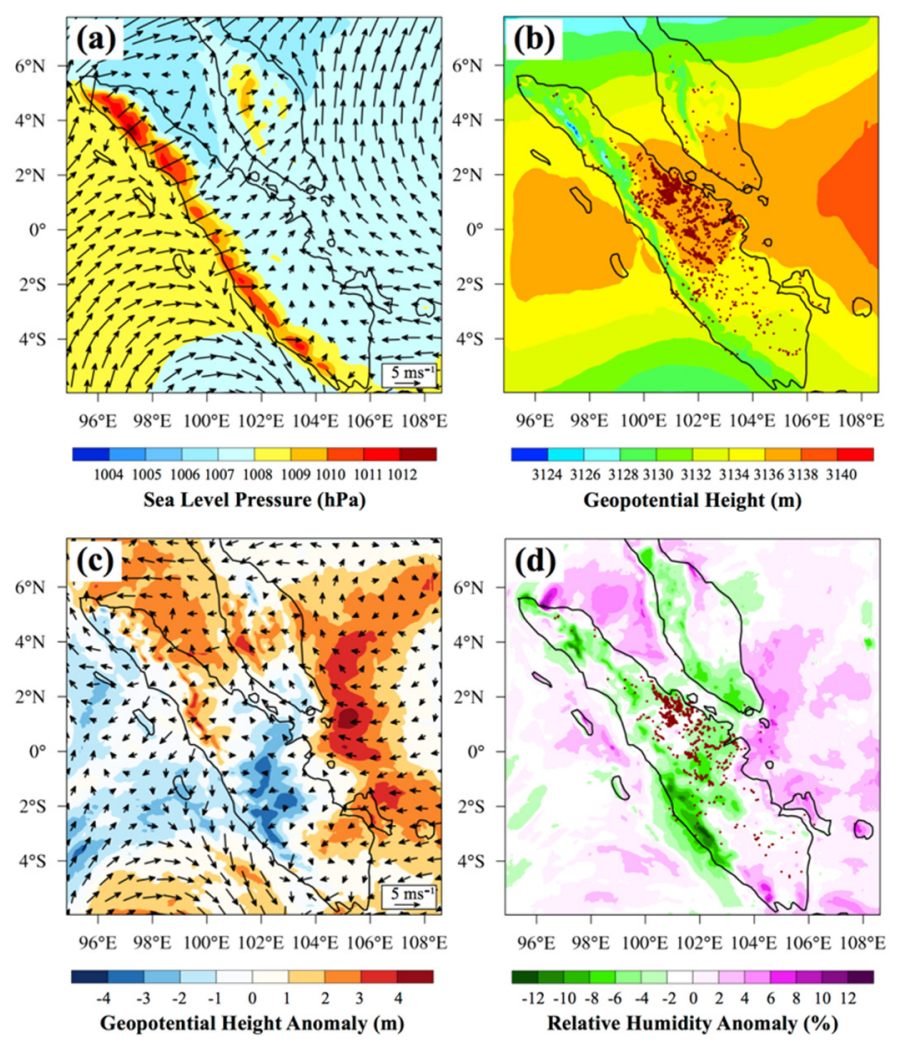

Figure 11. Subsidence and dryness over SPM during the June 2013 haze episode. WRF-Chem simulated (a) daily averaged sea level pressure (hPa) overlaid with $10 \mathrm{~m}$ wind fields $\left(\mathrm{m} \mathrm{s}^{-1}\right)$ and (b) geopotential height $(\mathrm{m})$ at $700 \mathrm{hPa}$ for the period 17-26 June 2013. (c) Geopotential height anomaly $(\mathrm{m})$ at 700 $\mathrm{hPa}$ overlaid with $10 \mathrm{~m}$ wind fields anomaly $\left(\mathrm{m} \mathrm{s}^{-1}\right)$, and (d) surface relative humidity anomaly (\%) between the periods 21-23 June 2013 and the remaining days of the period 17-26 June 2013. The red dots in (b) and (d) represent the total MODIS fire hotpots for the periods 17-26 June 2013 and 21-23 June 2013, respectively.

\section{Summary and Conclusions}

One of the worst episodes of biomass-burning haze over the MC occurred in June 2013. However, the magnitude for this timing was uncharacteristic of the seasonality of extreme fire events in the 
region. In order to study this peculiar case, the aerosol and meteorological characteristics over SEA during the study period of 17 to 25 June were investigated. MODIS fire hotspot detections showed that fire activity was concentrated over Central Sumatra during the haze episode, which corresponded to high AOD retrievals of at least 1.8 over the region. CMORPH precipitation fields for the same period also showed that precipitation was a maximum over the SCS while Central Sumatra was particularly dry. The AOT retrievals indicated that smoke was transported by southwesterlies, which prevail during the SWM season, towards the SCS where it was eventually scavenged out by precipitation associated with TC Bebinca.

Fire activity is a combination of economic need and meteorological opportunity. By the start of the drier southwest monsoon season, farmers have begun to clear land and prepare for burning. This study focused on three features of interest that created highly favourable fire weather in the study region, namely, ENSO, the MJO, and TC activity. The MEI time-series from 1980 to 2016 showed that neutral ENSO conditions prevailed during the June 2013 haze episode with an MEI value of -0.144 for that month. In contrast, the three worst episodes over the MC during that period occurred in 1982 to 1983,1997 to 1998, and 2015 when warm conditions prevailed. Major fire episodes usually occur between August and October in the MC. Therefore, the overall MODIS fire count over the MC in June 2013 expectedly ranked low as compared to bulk-burning months, which occurred during El-Nino years but were comparable to those during non-El Nino years. Comparing fire counts that occurred over only SPM, June 2013 was surprisingly comparable to El-Nino correlated episodes of 2002 and 2006. MODIS fire counts observed over SPM and the MC for June were the highest in 2013 as compared to any other year that MODIS Aqua and Terra satellites have been in operation, and the highest ratio of fire count for SPM to MC was recorded in June 2013. The nature of fire activity over SPM in June 2013 was, therefore, uncharacteristic for that period of the year under neutral ENSO conditions.

The mean daily precipitation for the month of June for the years 2003-2015 was also compared. In particular, data for June in 2003, 2004, 2005, 2009, 2012, and 2013 were investigated since notable fire episodes occurred during these periods. While dry conditions can be attributed to positive El-Nino conditions in June 2009 and 2012, June 2003 and 2004 were particularly dry despite the prevailing neutral ENSO conditions, possibly due to positive Modoki conditions during these two years. Interestingly, the fire count over SPM in June 2013 was much higher than in the drier months of June in 2003 and 2004. The MJO phase and amplitude time-series showed that phases 6-7 of the MJO prevailed over the MC in June 2013, inducing subsidence over the region. In contrast, the wet phase of the MJO prevailed in June 2003 while a weaker MJO event occurred in June 2004 as compared to June 2013. The MJO induced subsidence over SPM, therefore, contributed to increased burning over the region.

WRF-Chem was used to investigate the influence of TC Bebinca over the SCS on the haze event and was run from 14 to 27 June 2013. The model performance was evaluated by comparing the model results to $\mathrm{CMORPH}$ precipitation data, measured data at selected ground stations over Malaysia and CALIPSO and MODIS satellite data. The model succeeded to capture the location and magnitude of precipitation over the domain area and to predict the diurnal variation of $10 \mathrm{~m}$ wind speed and 2 $\mathrm{m}$ temperature, respectively. The modelled AOTs at $550 \mathrm{~nm}$ were also very similar to the observed MODIS AOT in patterns and magnitudes. WRF-Chem also successfully captured the variations in plume height as compared to the CALIOP-derived extinction profile. In 2013, the TC season over WNP was marked by an above average number of TCs. TC Bebinca was generated over the SCS during this active and early period of cyclone genesis, which could have been the result of the transiting MJO, and was found to have serious intensifying effects on the propagation of forest fires over Sumatra and the transport of haze over the MC. The model results showed that subsidence associated with Bebinca and the dry phases of the MJO contributed to regions of dryness over Central Sumatra and the migration of Bebinca from the SCS onto Indochina governed the direction of plume flow from Sumatra. In fact, the extreme haze event of June 2013 coincided with the presence of TC Bebinca. The WRF-Chem model results showed that while high pressure and dry conditions prevailed over SPM during the 
simulation period 17-26 June 2013, TC Bebinca induced further subsidence and dryness over Riau causing a $10 \%$ decrease in surface relative humidity during the three days when it was most intense. Therefore, intense and early TC seasons over the WNP can be an indication of the occurrence of early and extreme haze events over the MC. More importantly, the combined subsidence due to both Bebinca and the $\mathrm{MJO}$ is a phenomenon which requires further attention since no haze event occurred when stronger Category 1 Rumbia crossed the SCS during the lesser dry phase 8 of the MJO over the MC.

Author Contributions: Conceptualization, Y.O., A.C., J.W. and J.S.R.; methodology, Y.O.; software, Y.O., M.C.G.O., K.I.M.; formal analysis, Y.O.; writing-original draft preparation, Y.O.; writing-review and editing, Y.O., A.C., J.W., J.S.R., S.V.S. and M.C.G.O.; visualization, Y.O.; supervision, A.C.; project administration, Y.O. All authors have read and agreed to the published version of the manuscript.

Funding: The study was supported by the Malaysian Ministry of Science, Technology and Innovation (MOSTI) under the project: "Biomass burning haze (BBH) in Southeast Asia (SEA): Development of a computational tool to predict its transport and impacts on climate change in Malaysia", contract number 06-02-12-SF0346.

Acknowledgments: The first author is indebted to the research scholarships offered by the University of Nottingham Malaysia Campus. The authors wish to thank the DOE Malaysia for providing meteorological data in this work. The research work also forms part of The Seven South-East Asian Studies Mission (7SEAS) under the National Aeronautics and Space Administration (NASA), Office of Naval Research (ONR), and ONR Global. The authors are also grateful for access to the University of Nottingham High Performance Computing Facility. The contributions from J.W. and J.S.R. were provided by the NASA Interdisciplinary Science Program. The data used in this work are listed in the relevant figures and references.

Conflicts of Interest: The authors declare no conflict of interest.

\section{References}

1. Field, R.D.; van der Werf, G.R.; Shen, S.S.P. Human amplification of drought-induced biomass burning in Indonesia since 1960. Nat. Geosci. 2009, 2, 185-188. [CrossRef]

2. Giglio, L.; Csiszar, I.; Justice, C.O. Global distribution and seasonality of active fires as observed with the Terra and Aqua Moderate Resolution Imaging Spectroradiometer (MODIS) sensors. J. Geophys. Res. Biogeosci. 2006, 111. [CrossRef]

3. Reid, J.S.; Hyer, E.J.; Prins, E.M.; Westphal, D.L.; Zhang, J.; Wang, J.; Christopher, S.A.; Curtis, C.A.; Schmidt, C.C.; Eleuterio, D.P.; et al. Global Monitoring and Forecasting of Biomass-Burning Smoke: Description of and Lessons From the Fire Locating and Modeling of Burning Emissions (FLAMBE) Program. IEEE J. Sel. Top. Appl. Earth Obs. Remote Sens. 2009, 2, 144-162. [CrossRef]

4. Reid, J.S.; Xian, P.; Hyer, E.J.; Flatau, M.K.; Ramirez, E.M.; Turk, F.J.; Sampson, C.R.; Zhang, C.; Fukada, E.M.; Maloney, E.D. Multi-scale meteorological conceptual analysis of observed active fire hotspot activity and smoke optical depth in the Maritime Continent. Atmos. Chem. Phys. 2012, 12, 2117-2147. [CrossRef]

5. Quah, E.; Johnston, D. Forest fires and environmental haze in Southeast Asia: using the "stakeholder" approach to assign costs and responsibilities. J. Environ. Manag. 2001, 63, 181-191. [CrossRef]

6. $\quad$ Reid, J.S.; Hyer, E.J.; Johnson, R.S.; Holben, B.N.; Yokelson, R.J.; Zhang, J.; Campbell, J.R.; Christopher, S.A.; Di Girolamo, L.; Giglio, L.; et al. Observing and understanding the Southeast Asian aerosol system by remote sensing: An initial review and analysis for the Seven Southeast Asian Studies (7SEAS) program. Atmos. Res. 2013, 122, 403-468. [CrossRef]

7. Ward, E. Smoke from wildland fires. In Health Guidelines for Vegetation Fire Events. Background Papers; World Health Organization: Geneva, Switzerland, 1999; pp. 70-85.

8. Aditama, T.Y. Impact of haze from forest fire to respiratory health: Indonesian experience. Respirology 2000, 5, 169-174. [CrossRef]

9. Kunii, O.; Kanagawa, S.; Yajima, I.; Hisamatsu, Y.; Yamamura, S.; Amagai, T.; Ismail, I.T.S. The 1997 Haze Disaster in Indonesia: Its Air Quality and Health Effects. Arch. Environ. Heal. Int. J. 2002, 57, 16-22. [CrossRef]

10. Betha, R.; Pradani, M.; Lestari, P.; Joshi, U.M.; Reid, J.S.; Balasubramanian, R. Chemical speciation of trace metals emitted from Indonesian peat fires for health risk assessment. Atmos. Res. 2013, 122, 571-578. [CrossRef] 
11. Reid, J.S.; Eck, T.F.; Christopher, S.A.; Koppmann, R.; Dubovik, O.; Eleuterio, D.P.; Holben, B.N.; Reid, E.A.; Zhang, J. A review of biomass burning emissions part III: intensive optical properties of biomass burning particles. Atmos. Chem. Phys. 2005, 5, 827-849. [CrossRef]

12. Tsay, S.-C.; Hsu, N.C.; Lau, W.K.-M.; Li, C.; Gabriel, P.M.; Ji, Q.; Holben, B.N.; Judd Welton, E.; Nguyen, A.X.; Janjai, S.; et al. From BASE-ASIA toward 7-SEAS: A satellite-surface perspective of boreal spring biomass-burning aerosols and clouds in Southeast Asia. Atmos. Environ. 2013, 78, 20-34. [CrossRef]

13. Lin, N.-H.; Tsay, S.-C.; Maring, H.B.; Yen, M.-C.; Sheu, G.-R.; Wang, S.-H.; Chi, K.H.; Chuang, M.-T.; Ou-Yang, C.-F.; Fu, J.S.; et al. An overview of regional experiments on biomass burning aerosols and related pollutants in Southeast Asia: From BASE-ASIA and the Dongsha Experiment to 7-SEAS. Atmos. Environ. 2013, 78, 1-19. [CrossRef]

14. Rasmusson, E.M.; Wallace, J.M. Meteorological aspects of the El Nino/southern oscillation. Science (80-) 1983, 222, 1195-1202. [CrossRef] [PubMed]

15. McBride, J.L.; Haylock, M.R.; Nicholls, N. Relationships between the Maritime Continent Heat Source and the El Niño-Southern Oscillation Phenomenon. J. Clim. 2003, 16, 2905-2914. [CrossRef]

16. Nichol, J. Smoke haze in Southeast Asia: A predictable recurrence. Atmos. Environ. 1998, 32, $2715-2716$. [CrossRef]

17. Field, R.D.; Shen, S.S.P. Predictability of carbon emissions from biomass burning in Indonesia from 1997 to 2006. J. Geophys. Res. Biogeosci. 2008, 113, 1-17. [CrossRef]

18. Wang, J.; Ge, C.; Yang, Z.; Hyer, E.J.; Reid, J.S.; Chew, B.-N.; Mahmud, M.; Zhang, Y.; Zhang, M. Mesoscale modeling of smoke transport over the Southeast Asian Maritime Continent: Interplay of sea breeze, trade wind, typhoon, and topography. Atmos. Res. 2013, 122, 486-503. [CrossRef]

19. Field, R.D.; van der Werf, G.R.; Fanin, T.; Fetzer, E.J.; Fuller, R.; Jethva, H.; Levy, R.; Livesey, N.J.; Luo, M.; Torres, O.; et al. Indonesian fire activity and smoke pollution in 2015 show persistent nonlinear sensitivity to El Niño-induced drought. Proc. Natl. Acad. Sci. USA 2016, 113, 9204-9209. [CrossRef]

20. Madden, R.A.; Julian, P.R. Detection of a 40-50 Day Oscillation in the Zonal Wind in the Tropical Pacific. J. Atmos. Sci. 1971, 28, 702-708. [CrossRef]

21. Zhang, C. Madden-Julian Oscillation. Rev. Geophys. 2005, 43, RG2003. [CrossRef]

22. Wu, C.-H.; Hsu, H.-H. Topographic Influence on the MJO in the Maritime Continent. J. Clim. 2009, 22, 5433-5448. [CrossRef]

23. Zhang, C. Madden-Julian Oscillation: Bridging Weather and Climate. Bull. Am. Meteorol. Soc. 2013, 94, 1849-1870. [CrossRef]

24. Reid, J.S.; Lagrosas, N.D.; Jonsson, H.H.; Reid, E.A.; Sessions, W.R.; Simpas, J.B.; Uy, S.N.; Boyd, T.J.; Atwood, S.A.; Blake, D.R.; et al. Observations of the temporal variability in aerosol properties and their relationships to meteorology in the summer monsoonal South China Sea/East Sea: the scale-dependent role of monsoonal flows, the Madden-Julian Oscillation, tropical cyclones, squall lines and cold pools. Atmos. Chem. Phys. 2015, 15, 1745-1768. [CrossRef]

25. Oozeer, M.Y.; Chan, A.; Ooi, M.C.-G.; Zarzur, A.M.; Salinas, S.V.; Chew, B.-N.; Morris, K.I.; Choong, W.-K. Numerical Study of the Transport and Convective Mechanisms of Biomass Burning Haze in South-Southeast Asia. Aerosol Air Qual. Res. 2016, 16, 2950-2963. [CrossRef]

26. Vadrevu, K.P.; Lasko, K.; Giglio, L.; Justice, C. Analysis of Southeast Asian pollution episode during June 2013 using satellite remote sensing datasets. Environ. Pollut. 2014, 195, 245-256. [CrossRef]

27. Betha, R.; Behera, S.N.; Balasubramanian, R. 2013 Southeast Asian smoke haze: Fractionation of particulate-bound elements and associated health risk. Environ. Sci. Technol. 2014, 48, 4327-4335. [CrossRef]

28. Ho, R.C.; Zhang, M.W.; Ho, C.S.; Pan, F.; Lu, Y.; Sharma, V.K. Impact of 2013 south Asian haze crisis: study of physical and psychological symptoms and perceived dangerousness of pollution level. BMC Psychiatry 2014, 14, 81. [CrossRef]

29. Velasco, E.; Rastan, S. Air quality in Singapore during the 2013 smoke-haze episode over the Strait of Malacca: Lessons learned. Sustain. Cities Soc. 2015, 17, 122-131. [CrossRef]

30. Koplitz, S.N.; Mickley, L.J.; Jacob, D.J.; Marlier, M.E.; DeFries, R.S.; Gaveau, D.L.A.; Locatelli, B.; Reid, J.S.; Xian, P.; Myers, S.S. Role of the Madden-Julian Oscillation in the Transport of Smoke From Sumatra to the Malay Peninsula During Severe Non-El Niño Haze Events. J. Geophys. Res. Atmos. 2018, 123, 6282-6294. [CrossRef] 
31. Goh, A.Z.-C.; Chan, J.C.L. Interannual and interdecadal variations of tropical cyclone activity in the South China Sea. Int. J. Climatol. 2010, 30, 827-843. [CrossRef]

32. Ying, M.; Bai, L.; Zhan, R. Tropical Cyclone Activity over the western North Pacific in 2013. Trop. Cyclone Res. Rev. 2014, 3, 131-144.

33. Grell, G.A.; Peckham, S.E.; Schmitz, R.; McKeen, S.A.; Frost, G.; Skamarock, W.C.; Eder, B. Fully coupled "online" chemistry within the WRF model. Atmos. Environ. 2005, 39, 6957-6975. [CrossRef]

34. Fast, J.D.; Gustafson, W.I.; Easter, R.C.; Zaveri, R.A.; Barnard, J.C.; Chapman, E.G.; Grell, G.A.; Peckham, S.E. Evolution of ozone, particulates, and aerosol direct radiative forcing in the vicinity of Houston using a fully coupled meteorology-chemistry-aerosol model. J. Geophys. Res. Atmos. 2006, 111, 1-29. [CrossRef]

35. Wu, L.; Su, H.; Jiang, J.H. Regional simulations of deep convection and biomass burning over South America: 1. Model evaluations using multiple satellite data sets. J. Geophys. Res. Atmos. 2011, 116, 1-14. [CrossRef]

36. Wu, L.; Su, H.; Jiang, J.H. Regional simulations of deep convection and biomass burning over South America: 2. Biomass burning aerosol effects on clouds and precipitation. J. Geophys. Res. 2011, 116, D17209. [CrossRef]

37. Lin, C.-Y.; Zhao, C.; Liu, X.; Lin, N.-H.; Chen, W.-N. Modelling of long-range transport of Southeast Asia biomass-burning aerosols to Taiwan and their radiative forcings over East Asia. Tellus B 2014, 66. [CrossRef]

38. Aouizerats, B.; van der Werf, G.R.; Balasubramanian, R.; Betha, R. Importance of transboundary transport of biomass burning emissions to regional air quality in Southeast Asia during a high fire event. Atmos. Chem. Phys. 2015, 15, 363-373. [CrossRef]

39. Ge, C.; Wang, J.; Reid, J.S. Mesoscale modeling of smoke transport over the Southeast Asian Maritime Continent: Coupling of smoke direct radiative effect below and above the low-level clouds. Atmos. Chem. Phys. 2014, 14, 159-174. [CrossRef]

40. Miettinen, J.; Liew, S.C. Burn-scar patterns and their effect on regional burnt-area mapping in insular South-East Asia. Int. J. Wildl. Fire 2009, 18, 837. [CrossRef]

41. Levy, R.C.; Mattoo, S.; Munchak, L.A.; Remer, L.A.; Sayer, A.M.; Patadia, F.; Hsu, N.C. The Collection 6 MODIS aerosol products over land and ocean. Atmos. Meas. Tech. 2013, 6, 2989-3034. [CrossRef]

42. Joyce, R.J.; Janowiak, J.E.; Arkin, P.A.; Xie, P. CMORPH: A Method that Produces Global Precipitation Estimates from Passive Microwave and Infrared Data at High Spatial and Temporal Resolution. J. Hydrometeorol. 2004, 5, 487-503. [CrossRef]

43. Janowiak, J.E.; Kousky, V.E.; Joyce, R.J. Diurnal cycle of precipitation determined from the CMORPH high spatial and temporal resolution global precipitation analyses. J. Geophys. Res. 2005, 110, D23105. [CrossRef]

44. Dinku, T.; Chidzambwa, S.; Ceccato, P.; Connor, S.J.; Ropelewski, C.F. Validation of high-resolution satellite rainfall products over complex terrain. Int. J. Remote Sens. 2008, 29, 4097-4110. [CrossRef]

45. Sapiano, M.R.P.; Arkin, P.A. An Intercomparison and Validation of High-Resolution Satellite Precipitation Estimates with 3-Hourly Gauge Data. J. Hydrometeorol. 2009, 10, 149-166. [CrossRef]

46. Shen, Y.; Xiong, A.; Wang, Y.; Xie, P. Performance of high-resolution satellite precipitation products over China. J. Geophys. Res. 2010, 115, D02114. [CrossRef]

47. Wheeler, M.C.; Hendon, H.H. An All-Season Real-Time Multivariate MJO Index: Development of an Index for Monitoring and Prediction. Mon. Weather Rev. 2004, 132, 1917-1932. [CrossRef]

48. GES DISC Northern Eurasian Earth Science Partnership Initiative Project MOD14CM1: MODIS/Terra 1 degree Gridded MODIS Active Fire Product V005. Available online: http://disc.gsfc.nasa.gov/datacollection/ MOD14CM1_005.html (accessed on 1 April 2016).

49. GES DISC Northern Eurasian Earth Science Partnership Initiative Project MYD14CM1: MODIS/Aqua 1 degree Gridded MODIS Active Fire Product V005. Available online: http://disc.gsfc.nasa.gov/datacollection/ MYD14CM1_005.html (accessed on 1 April 2016).

50. Justice, C.; Giglio, L.; Korontzi, S.; Owens, J.; Morisette, J.; Roy, D.; Descloitres, J.; Alleaume, S.; Petitcolin, F.; Kaufman, Y. The MODIS fire products. Remote Sens. Environ. 2002, 83, 244-262. [CrossRef]

51. Giglio, L.; Descloitres, J.; Justice, C.O.; Kaufman, Y.J. An Enhanced Contextual Fire Detection Algorithm for MODIS. Remote Sens. Environ. 2003, 87, 273-282. [CrossRef]

52. Wolter, K.; Timlin, M.S. Measuring the strength of ENSO events: How does 1997/98 rank? Weather 1998, 53, 315-324. [CrossRef]

53. Sessions, W.R.; Fuelberg, H.E.; Kahn, R.A.; Winker, D.M. An investigation of methods for injecting emissions from boreal wildfires using WRF-Chem during ARCTAS. Atmos. Chem. Phys. 2011, 11, 5719-5744. [CrossRef] 
54. Janjić, Z.I. The Step-Mountain Eta Coordinate Model: Further Developments of the Convection, Viscous Sublayer, and Turbulence Closure Schemes. Mon. Weather Rev. 1994, 122, 927-945. [CrossRef]

55. Janjić, Z.I. Comments on "Development and Evaluation of a Convection Scheme for Use in Climate Models". J. Atmos. Sci. 2000, 57, 3686.

56. Kain, J.S. The Kain-Fritsch Convective Parameterization: An Update. J. Appl. Meteorol. 2004, 43, $170-181$. [CrossRef]

57. Grell, G.A.; Dévényi, D. A generalized approach to parameterizing convection combining ensemble and data assimilation techniques. Geophys. Res. Lett. 2002, 29, 1693. [CrossRef]

58. Ge, C.; Wang, J.; Reid, J.S.; Posselt, D.J.; Xian, P.; Hyer, E. Mesoscale modeling of smoke transport from equatorial Southeast Asian Maritime Continent to the Philippines: First comparison of ensemble analysis with in situ observations. J. Geophys. Res. Atmos. 2017, 122, 5380-5398. [CrossRef]

59. Pennelly, C.; Reuter, G.; Flesch, T. Verification of the WRF model for simulating heavy precipitation in Alberta. Atmos. Res. 2014, 135-136, 172-192. [CrossRef]

60. Berrisford, P.; Dee, D.P.; Fielding, K.; Fuentes, M.; Kallberg, P.; Kobayashi, S.; Uppala, S.M. The ERA-Interim Archive; ERA Report Series; Technical Report 1; ECMWF: Reading, UK, 2009.

61. Lin, Y.-L.; Farley, R.D.; Orville, H.D. Bulk Parameterization of the Snow Field in a Cloud Model. J. Clim. Appl. Meteorol. 1983, 22, 1065-1092. [CrossRef]

62. Mlawer, E.J.; Taubman, S.J.; Brown, P.D.; Iacono, M.J.; Clough, S.A. Radiative transfer for inhomogeneous atmospheres: RRTM, a validated correlated-k model for the longwave. J. Geophys. Res. Atmos. 1997, 102, 16663-16682. [CrossRef]

63. Pincus, R.; Barker, H.W.; Morcrette, J.-J. A fast, flexible, approximate technique for computing radiative transfer in inhomogeneous cloud fields. J. Geophys. Res. Atmos. 2003, 108, 4376. [CrossRef]

64. Chen, F.; Dudhia, J. Coupling an Advanced Land Surface-Hydrology Model with the Penn State-NCAR MM5 Modeling System. Part I: Model Implementation and Sensitivity. Mon. Weather Rev. 2001, 129, 569-585. [CrossRef]

65. Janjic, Z. The surface layer in the NCEP Eta Model. In Proceedings of the Eleventh Conference on Numerical Weather Prediction; American Meteorological Society: Norfolk, VA, USA, 1996; pp. 354-355.

66. Janjic, Z. Nonsingular Implementation of the Mellor-Yamada Level 2. 5 Scheme in the NCEP Meso model. NCEP Off. Note 2002, 437, 1-61.

67. Stockwell, W.R.; Middleton, P.; Chang, J.S.; Tang, X. The second generation regional acid deposition model chemical mechanism for regional air quality modeling. J. Geophys. Res. Atmos. 1990, 95, 16343-16367. [CrossRef]

68. Ackermann, I.J.; Hass, H.; Memmesheimer, M.; Ebel, A.; Binkowski, F.S.; Shankar, U. Modal Aerosol Dynamics model for Europe: Development and first applications. Atmos. Environ. 1998, 32, 2981-2999. [CrossRef]

69. Schell, B.; Ackermann, I.J.; Hass, H.; Binkowski, F.S.; Ebel, A. Modeling the formation of secondary organic aerosol within a comprehensive air quality model system. J. Geophys. Res. 2001, 106, 28275. [CrossRef]

70. Wang, J.; Christopher, S.A.; Nair, U.S.; Reid, J.S.; Prins, E.M.; Szykman, J.; Hand, J.L. Mesoscale modeling of Central American smoke transport to the United States: 1. "Top-down" assessment of emission strength and diurnal variation impacts. J. Geophys. Res. Atmos. 2006, 111, 1-21. [CrossRef]

71. Fisher, J.A.; Jacob, D.J.; Purdy, M.T.; Kopacz, M.; Le Sager, P.; Carouge, C.; Holmes, C.D.; Yantosca, R.M.; Batchelor, R.L.; Strong, K.; et al. Source attribution and interannual variability of Arctic pollution in spring constrained by aircraft (ARCTAS, ARCPAC) and satellite (AIRS) observations of carbon monoxide. Atmos. Chem. Phys. 2010, 10, 977-996. [CrossRef]

72. Winker, D.M.; Pelon, J.; Coakley, J.A.; Ackerman, S.A.; Charlson, R.J.; Colarco, P.R.; Flamant, P.; Fu, Q.; Hoff, R.M.; Kittaka, C.; et al. The CALIPSO Mission: A Global 3D View of Aerosols and Clouds. Bull. Am. Meteorol. Soc. 2010, 91, 1211-1229. [CrossRef]

73. Chang, C.P.; Wang, Z.; McBride, J.; Liu, C.H. Annual cycle of Southeast Asia - Maritime continent rainfall and the asymmetric monsoon transition. J. Clim. 2005, 18, 287-301. [CrossRef]

74. Moron, V.; Robertson, A.W.; Boer, R. Spatial Coherence and Seasonal Predictability of Monsoon Onset over Indonesia. J. Clim. 2009, 22, 840-850. [CrossRef]

75. Wang, B.; Huang, F.; Wu, Z.; Yang, J.; Fu, X.; Kikuchi, K. Multi-scale climate variability of the South China Sea monsoon: A review. Dyn. Atmos. Ocean. 2009, 47, 15-37. [CrossRef] 
76. Reid, J.S.; Lagrosas, N.D.; Jonsson, H.H.; Reid, E.A.; Atwood, S.A.; Boyd, T.J.; Ghate, V.P.; Lynch, P.; Posselt, D.J.; Simpas, J.B.; et al. Aerosol meteorology and Philippine receptor observations of Maritime Continent aerosol emissions for the 2012 7SEAS southwest monsoon intensive study. Atmos. Chem. Phys. Discuss. 2016, 1-61. [CrossRef]

77. Napitu, A.M.; Gordon, A.L.; Pujiana, K. Intraseasonal Sea Surface Temperature Variability across the Indonesian Seas*. J. Clim. 2015, 28, 8710-8727. [CrossRef]

78. Radojevic, M. Chemistry of Forest Fires and Regional Haze with Emphasis on Southeast Asia. Pure Appl. Geophys. 2003, 160, 157-187. [CrossRef]

79. Fuller, D.O. MODIS data used to study 2002 fires in Kalimantan, Indonesia. Eos, Trans. Am. Geophys. Union 2003, 84, 189-192. [CrossRef]

80. Mahmud, M. Mesoscale equatorial wind prediction in Southeast Asia during a haze episode of 2005. Geofizika 2009, 26, 67-84.

81. Hamada, Y.; Darung, U.; Limin, S.H.; Hatano, R. Characteristics of fire-generated gas emission observed during a large peatland fire in 2009 at Kalimantan, Indonesia. Atmos. Environ. 2013, 74, 177-181. [CrossRef]

82. Ashok, K.; Behera, S.K.; Rao, S.A.; Weng, H.; Yamagata, T. El Niño Modoki and its possible teleconnection. J. Geophys. Res. 2007, 112, C11007. [CrossRef]

83. Cheng, W.Y.Y.; Steenburgh, W.J. Evaluation of surface sensible weather forecasts by the WRF and the Eta models over the western United States. Weather Forecast. 2005, 20, 812-821. [CrossRef]

84. Mass, C.; Ovens, D. Fixing WRF's high speed wind bias: A new subgrid scale drag parameterization and the role of detailed verification. In Proceedings of the 24th Conference on Weather and Forecasting and 20th Conference on Numerical Weather Prediction Preprints 91st American Meteorological Society Annual Meeting; American Meteorological Society: Seattle, WA, USA, 2011; Volume 23727.

85. Jiménez, P.A.; Dudhia, J. Improving the Representation of Resolved and Unresolved Topographic Effects on Surface Wind in the WRF Model. J. Appl. Meteorol. Climatol. 2012, 51, 300-316. [CrossRef]

86. Gómez-Navarro, J.J.; Raible, C.C.; Dierer, S. Sensitivity of the WRF model to PBL parametrisations and nesting techniques: Evaluation of wind storms over complex terrain. Geosci. Model Dev. 2015, 8, 3349-3363. [CrossRef]

87. Huang, J.; Hsu, N.C.; Tsay, S.-C.; Jeong, M.-J.; Holben, B.N.; Berkoff, T.A.; Welton, E.J. Susceptibility of aerosol optical thickness retrievals to thin cirrus contamination during the BASE-ASIA campaign. J. Geophys. Res. 2011, 116, D08214. [CrossRef]

88. Neumann, C.J. Global overview. In Global Guide to Tropical Cyclone Forecasting; WMO/TC-No. 560; World Meteorological Organization: Geneva, Switzerland, 1993.

89. Chen, L.; Ding, Y. The Conspectus of Western Pacific Typhoon; Science Press: Beijing, China, 1979.

90. Gray, W.M. Hurricanes: Their formation, structure and likely role in the tropical circulation. Meteorol. Trop. Ocean. 1979, 77, 155-218.

91. Maloney, E.D.; Hartmann, D.L. The Madden-Julian Oscillation, Barotropic Dynamics, and North Pacific Tropical Cyclone Formation. Part I: Observations. J. Atmos. Sci. 2001, 58, 2545-2558. [CrossRef]

92. Kim, J.-H.; Ho, C.-H.; Kim, H.-S.; Sui, C.-H.; Park, S.K. Systematic Variation of Summertime Tropical Cyclone Activity in the Western North Pacific in Relation to the Madden-Julian Oscillation. J. Clim. 2008, 21, 1171-1191. [CrossRef]

(C) 2020 by the authors. Licensee MDPI, Basel, Switzerland. This article is an open access article distributed under the terms and conditions of the Creative Commons Attribution (CC BY) license (http://creativecommons.org/licenses/by/4.0/). 